NBER WORKING PAPER SERIES

\title{
EFFECTS OF TERMS OF TRADE GAINS AND TARIFF CHANGES ON THE MEASUREMENT OF U.S. PRODUCTIVITY GROWTH
}

\author{
Robert C. Feenstra \\ Benjamin R. Mandel \\ Marshall B. Reinsdorf \\ Matthew J. Slaughter \\ Working Paper 15592 \\ http://www.nber.org/papers/w15592 \\ NATIONAL BUREAU OF ECONOMIC RESEARCH \\ 1050 Massachusetts Avenue \\ Cambridge, MA 02138 \\ December 2009
}

We are grateful for Mike Harper's assistance with the analysis of the productivity measurement implications. We draw heavily upon Alterman, Diewert and Feenstra (1999), and the authors are indebted to Bill Alterman and Erwin Diewert for that earlier study which we apply here to U.S. productivity growth. For helpful comments we thank seminar participants at Columbia, Harvard, Oxford, and the NBER. For financial support Feenstra and Slaughter thank the National Science Foundation. Finally, the views expressed in this paper are those of the authors, not those of the Bureau of Economic Analysis, and should not be interpreted as reflecting the views of the Board of Governors of the Federal Reserve System or of any other person associated with the Federal Reserve System. The views expressed herein are those of the author(s) and do not necessarily reflect the views of the National Bureau of Economic Research.

NBER working papers are circulated for discussion and comment purposes. They have not been peerreviewed or been subject to the review by the NBER Board of Directors that accompanies official NBER publications.

(C) 2009 by Robert C. Feenstra, Benjamin R. Mandel, Marshall B. Reinsdorf, and Matthew J. Slaughter. All rights reserved. Short sections of text, not to exceed two paragraphs, may be quoted without explicit permission provided that full credit, including (C) notice, is given to the source. 
Effects of Terms of Trade Gains and Tariff Changes on the Measurement of U.S. Productivity

Growth

Robert C. Feenstra, Benjamin R. Mandel, Marshall B. Reinsdorf, and Matthew J. Slaughter

NBER Working Paper No. 15592

December 2009

JEL No. F43,O47

\begin{abstract}
$\underline{\text { ABSTRACT }}$
Since 1995, growth in productivity in the United States appears to have accelerated dramatically. In this paper, we argue that part of this apparent speed-up actually represents gains in the terms of trade and tariff reductions, especially for information-technology products. We demonstrate how unmeasured gains in the terms of trade and declines in tariffs can cause conventionally measured growth in real output and productivity to be overstated. Building on the GDP function approach of Diewert and Morrison, we develop methods for measuring these effects. From 1995 through 2006, the average growth rates of our alternative price indexes for U.S. imports are $1.5 \%$ per year lower than the growth rate of price indexes calculated using official methods. Thus properly measured terms-of-trade gain can account for close to 0.2 percentage points per year, or about 20\%, of the 1995-2006 apparent increase in productivity growth for the U.S. economy. Bias in the price indexes used to deflate domestic output is a question beyond the scope of this paper, but if upward bias were also present in those indexes, this could offset some of the effects of mismeasurement of gains in terms of trade.
\end{abstract}

Robert C. Feenstra

Department of Economics

University of California, Davis

One Shields Avenue

Davis, CA 95616

and NBER

rcfeenstra@ucdavis.edu

Benjamin R. Mandel

Federal Reserve Board of Governors

20th and C Street

Washington, DC 20551

Benjamin.R.Mandel@frb.gov
Marshall B. Reinsdorf

Bureau of Economic Analysis

US Department of Commerce

1441 L Street, NW, Mail Stop BE-40

Washington, DC 20230

marshall.reinsdorf@bea.gov

Matthew J. Slaughter

Tuck School of Business

Dartmouth College

100 Tuck Hall

Hanover, NH 03755

and NBER

matthew.j.slaughter@dartmouth.edu 


\section{Introduction}

The single best measure of a country's average standard of living is its productivity: the value of output of goods and services a country produces per unit of factor inputs. The more workers produce, the more income they receive and the more they can consume. Higher productivity thus brings higher standards of living. Understanding the causes and proper measurement of productivity growth has long been a central research area in economics.

In the United States, since 1995 growth in aggregate labor productivity appears to have accelerated markedly. The U.S. Bureau of Labor Statistics (BLS) reports that from 1973 to 1995, output per worker hour in the nonfarm business sector grew on average at just $1.40 \%$ per year. From 1995 through 2007 this rate accelerated to an average of $2.48 \%$ per year. ${ }^{1}$ If sustained, this speed-up in U.S. productivity growth would carry dramatic implications for the U.S. economy. At the previous generation's average annual growth rate of $1.40 \%$, average U.S. living standards were taking 50 years to double. Should the more-recent average annual growth rate of $2.48 \%$ persist, then average U.S. living standards would take just 29 years to double-a generation faster.

A large literature has in recent years analyzed this improvement in U.S. productivity growth. The declining prices of information technology (IT) products, which accelerated in the late 1990s, are often credited with key direct and indirect roles in the productivity speedup. For example, Jorgenson (2001, p. 2) argues that: “The accelerated information technology price decline signals faster productivity growth in IT-producing industries. In fact, these industries have been the source of most of aggregate productivity growth throughout the 1990s."2

\footnotetext{
${ }^{1}$ These calculations are based on BLS data series \#PRS85006092, as reported at www.bls.gov. Similar trends are evident in the BLS measures of multifactor productivity (MFP) for the private business sector, which we graph in Figure 1. We note that since 2002, however, U.S. productivity growth appears to have decelerated again.

${ }^{2}$ Similarly, Oliner and Sichel (2000, p. 17) state that, “In accord with the 'dual' framework described above, we have interpreted the sharp decline in semiconductor prices after 1995 as signaling a pickup in that sector’s TFP growth.” On the indirect role of IT in the productivity speedup, Jorgenson (2001, p. 22) finds that, "In response to these [IT] price changes, firms, households, and governments have accumulated computers, software, and
} 
In this paper, we argue that part of the apparent speed-up in U.S. productivity growth actually represented gains in the terms of trade and tariff reductions, especially for informationtechnology products. We demonstrate how unmeasured gains in the terms of trade and declines in tariffs caused conventionally measured U.S. real output and productivity to be overstated. ${ }^{3}$

The starting point for our argument is the observation that on many measures, the global engagement of the U.S. IT industry deepened after 1995—-precisely the period of accelerated IT price declines that have been interpreted as total factor productivity (TFP). Particularly important was the Information Technology Agreement, a comprehensive free-trade agreement that to date remains the only agreement during the life of the World Trade Organization. Ratified in 1996 by dozens of countries accounting for nearly 95 percent of world IT trade, the ITA eliminated all world tariffs on hundreds of IT products in four stages from early 1997 through 2000. This timing suggests that the ITA, which we discuss in Section 2, may have played an important role in the post-1995 trend in IT prices.

Further initial evidence for our argument appears in Figure 1, which plots three series. One is the U.S. terms of trade based on series reported by the BLS: i.e., the ratio of the U.S. export-price index to its non-petroleum (to exclude the outsize role played by fluctuations in oil prices) import price index. The BLS uses a Laspeyres formula to construct price these trade-price indexes, based on price quotes it collects from importing and exporting firms. For our analysis in this paper we had access to these raw price-quote data for September 1993 through December 2006, and so in Figure 1 we have plotted our own terms of trade for that time period (calculated

communications equipment much more rapidly than other forms of capital.” Prominent studies of the U.S. productivity acceleration include Baily and Lawrence (2001), Bosworth and Triplett (2000), Gordon (2000, 2003), Jorgenson (2001), Jorgenson and Stiroh (2000a,b), Nordhaus (2001, 2005), and Oliner and Sichel (2000, 2002).

${ }^{3}$ See also Mann (2003) and Houseman (2007), who express similar viewpoints. 
following BLS methods). ${ }^{4}$ And the third series in Figure 1, also from the BLS, is U.S. multifactor productivity for the non-farm business sector.

U.S. multifactor productivity growth rose from $0.53 \%$ per year during $1987-1995$ to $1.41 \%$ per year during 1996-2006. This index of U.S. terms of trade shows a declining trend up until 1995 in Figure 1. But since 1995—at precisely the time that productivity growth picked upU.S. terms of trade reversed and began rising, with a string of solid gains from 1995 through 2006. The average annual gain in the U.S. non-petroleum terms of trade from 1995 through 2006 was $1.0 \%$, implying a cumulative gain nearly as large as the $15 \%$ deterioration in terms of trade from the petroleum price shocks in 1973-74 and 1979-80. The fact that U.S. terms of trade began to improve precisely when productivity accelerated suggests a connection between the two.

What this link might be, however, is not immediately clear from standard theories of trade and growth. Kehoe and Ruhl (2008) have recently argued that changes in the terms of trade have no impact on productivity when tariffs are zero. When tariffs are present but small, then the impact of terms of trade shocks on productivity is correspondingly small. In Section 3, we will extend the analysis of Kehoe and Ruhl (2008) from a one-sector to a multi-sector model and similarly consider tariff reductions. In our multi-good setting, tariff reductions and changes in the terms of trade have only a second-order impact on GDP and productivity.

If the terms of trade are mismeasured, however, the story is critically different. Unmeasured changes in the terms of trade have a first-order impact on conventionally measured productivity growth. In particular, if the reduction in import prices is understated then conventionally measured productivity growth will be correspondingly overstated.

There are three important reasons that the U.S. terms of trade are mismeasured. First, as

\footnotetext{
${ }^{4}$ Our Laspeyres terms-of-trade index does not exactly match the one constructed from published BLS indexes due to missing data for some industries, but the difference is immaterial.
} 
already noted, the BLS import and export prices indexes are Laspeyres indexes, rather than a superlative formula. Second, in the calculation of GDP imports exclude duties, and the BLS import indexes_-which the Bureau of Economic Analysis (BEA) uses to deflate imports—also measure import prices free of tariffs. The relevant import prices facing firms, however, include these trade barriers. And third, the BLS import price index does not account for increases in the variety of imports coming from new supplying countries. As demonstrated by work including Feenstra (1994), Hummels and Klenow (2006), and Broda and Weinstein (2006), the economic impact of expanding varieties is large and therefore critical to account for. In Section 4 we construct price indexes that correct for all three of these errors, and in Section 5 we analyze the impact of the ITA on the prices and variety of high-technology products to show that high-tech products are especially affected by these sources of mismeasurement.

In terms of Figure 1, this key part of our overall argument is that the actual improvement in U.S. terms of trade was even higher than the reported BLS measures. To preview our main results, Figure 2 shows several alternative terms-of-trade indexes based on our calculations in this paper. We repeat from Figure 1 the BLS and our computed Laspeyres indexes and then show three others: (i) an exact Törnqvist index for the terms of trade; (ii) the Törnqvist index that also incorporates tariffs into the import prices; (iii) the Törnqvist index that incorporates both tariffs and also import variety. ${ }^{5}$

The key message of Figure 2 is that corrected for these three measurement errors, actual U.S. terms of trade were rising much faster that officially reported. The cumulative impact of these three adjustments means that the rise to just December 1999 in the Törnqvist index that

\footnotetext{
5 The first two of these indexes are set equal to the Laspeyres index in September 1993, the beginning of our sample period, whereas the variety adjustment (which is annual) begins in 1990. It is noteworthy that most of the variety adjustment occurs in the period since 1995, however, just like our other two adjustments.
} 
incorporates tariffs and variety was nearly equal to the cumulative rise in the Laspeyres index all the way to December 2006 (compare Figures 1 and 2). While the Laspeyres terms of trade constructed from BLS export and import price indexes rose about 0.9\% per year over 1995-2006, the Törnqvist index incorporating tariffs and import variety rose more than twice as fast, at $2.2 \%$ per year over the same period. The true terms-of-trade gain for the United States since 1995 has been much higher than indicated by official price indexes.

From our corrected terms-of-trade indexes in Figure 2 alone, however, we cannot infer how unmeasured terms-of-trade gains alter reported U.S. productivity growth. The reason is that BLS's aggregate export and import indexes play no direct role in BEA's measures of real output growth, which drive the calculations of productivity growth. Rather, BEA constructs GDP deflators from detailed industry export and import price indexes, generally the five-digit Enduse indexes produced by BLS, using a chained Fisher formula and GDP weights.

Accordingly, to estimate the impact of mismeasured terms of trade on reported productivity growth in Section 6 we constructed a full set of corrected Enduse export and import price indexes at the 5-digit. We then aggregate these detailed indexes using a chained Fisher index formula, with weights reflecting industry importance in GDP. We repeated this exercise for four alternative sets of detailed indexes: Laspeyres indexes that mimic official BLS indexes (as a benchmark); Törnqvist indexes; Törnqvist indexes including tariffs; and Törnqvist indexes including tariffs and a correction for new varieties. In each case, the result is alternative deflators for GDP and for the subset of GDP that excludes government, the gross value added of private business. ${ }^{6}$ Each alternative set of deflators, when applied to nominal GDP and its subsets, yields alternative measures of real output and thus of productivity growth. ${ }^{7}$

\footnotetext{
${ }^{6}$ In analyzing TFP for a sector, the conceptually correct measure of output is the sector's gross sales outside the sector, which equal its value added plus its purchases of intermediate inputs from outside the sector. The output
} 
By comparing productivity growth calculated from our three sets of alternative corrected price indexes with that obtained with our reconstructed official BLS indexes, we thus can estimate the portion of conventionally reported U.S. productivity growth that was actually due to unmeasured gains in terms of trade and declines in tariffs. Our corrected price deflators rise faster than the official deflator, and so our corrected real output and productivity growth are lower. Our preferred estimates are that properly measured terms-of-trade gains and tariff reductions account for close to 0.2 percentage points—about 20\%—of the reported 1996-2006 increase in U.S. productivity growth. Section 7 concludes.

\section{Globalization of the Information Technology Industry}

To see the role of international trade in measuring productivity, a sensible starting point is to examine the role of globalization in the IT industry. Current-dollar trade flows for some of the highest-profile IT sectors - computers, peripherals and semiconductors (Enduse category 213) and telecommunication equipment (Enduse 214) ${ }^{8}$ - are reported in Table 1 for three years spanning most of the 1990s. The bottom of Table 1 also reports the share of economy-wide trade flows accounted for by these industries.

Over the 1990s exports in these sectors have been rising faster than the national total, such that their share of that total rose from $10.7 \%$ to $15.4 \%$. But a more striking feature is the even higher level of imports in these sectors: over the 1990s their national import share rose from $12 \%$ to $16 \%$. This means that these two central IT sectors are substantial net importers whose trade

concept for the private business sector ought therefore to equal its value added plus imported intermediate inputs, and imported intermediates ought to be included in inputs. However, including imported intermediates in inputs instead of netting them out of the output measure was found to have little effect on TFP estimates, so BLS measures the output of private business by its value added. See Gullikson and Harper (1999, p. 50 and fn 29).

${ }^{7}$ The effects of our alternative detailed price indexes on the measure of productivity growth are generally the same as the effects we calculate on real output growth. Except that, as we note below, inputs of capital services used to estimate TFP are sensitive to the price indexes for imported capital goods. 
imbalance widened during the decade. Within these sectors, computers and semiconductors show the smallest trade deficits, while computer accessories and telecommunication equipment have the largest deficits. By 2000 the combined trade deficit in these IT sectors was $\$ 57$ billion, or fully 17 percent of the non-oil U.S. trade deficit that year. In subsequent years U.S. government industry classifications changed, but in 2008 in a similarly defined industry - information and communications - the United States ran a trade deficit of \$104.3 billion.

Table 2 offers some additional evidence on the trade intensity of IT industries, defined as trade flows as a share of output. For 1997, Table 2 shows exports, imports, and net exports, all as a share of output for two IT industries (slightly different from the Enduse classifications in Table 1): computers and peripheral equipment, and semiconductors and electronic components. The key message of Table 2 is that IT industries are much more trade intensive than the overall U.S. economy. In these industries both exports and imports as a share of output range between 19 and 38\%. These measures of trade intensity are higher than manufacturing industries in general, for which exports and imports were just 14-21\% of output. Taken together, Tables 1 and 2 indicate that many of the central IT industries in the United States are more trade-intensive than is the rest of the economy, and are substantial net importers.

There are many factors that contributed to the increasing globalization of the IT industry, including the creation and spread of global production networks. But in the second-half of the 1990's, one event in the global economy was of particular importance. Under the auspices of the World Trade Organization (WTO), an Information Technology Agreement (ITA) committed signatory countries to eliminate all tariffs on a wide range of nearly 200 IT products. These products covered both finished and intermediate goods such as computers and networking and peripheral

\footnotetext{
${ }^{8}$ The Enduse industry classification is used by the BEA for measuring GDP, so we also use it here. Trade data for Enduse industries comes from Bureau of the Census, 1992-2000.
} 
equipment; circuit boards and other passive/active components; semiconductors and their manufacturing equipment; software products and media; and telecommunications equipment.

The original Ministerial Declaration on Trade in Information Technology Products was concluded in December 1996 at the first WTO Ministerial in Singapore. This declaration stipulated that for the ITA to take effect, signatory countries would have to collectively represent at least $90 \%$ of world trade in the covered products. The 29 original signatories accounted for only about $83 \%$ of covered trade. But by April 1997 many more countries had signed on to push the share over 90\%, and the agreement entered into force in July 1997. Ultimately there were more than 50 ITA signatories that accounted for more than $95 \%$ of world trade in the covered ITA products. All ITA signatories agreed to reduce to zero their tariffs for all covered ITA products in four equal-rate reductions starting in 1997 and ending no later than the start of $2000 .^{9}$ Some developing countries were granted permission to extend rate cuts beyond 2000, but no later than 2005. Also, an ITA Review Committee was established to monitor compliance. The overarching goal of the ITA was to eliminate world tariffs in a wide range of IT products. Thanks to the number and commitment of signatory countries, it virtually achieved that goal.

The tariff reductions over 1997-2000 experienced by a number of U.S. ICT industries are shown in Table 3. The ITA tariff cuts are defined at the 8-digit level of the Harmonized System (HS) system, used to track import commodities. In the second column of Table 3, we indicate the percentage of import value within each industry that are covered by ITA commodities. For computers, peripherals and semiconductors, $100 \%$ of imports were included in the ITA tariff cuts. In the smaller industry of blank tapes for audio and visual use, $90 \%$ of the imports were covered by the ITA, and in the large sector of telecommunication equipment, $80 \%$ of the import value was

\footnotetext{
${ }^{9}$ The four tariff cuts for the U.S. occurred in July 1997, January 1998, January 1999, and for a small number of commodities, January 2000.
} 
covered by the ITA. Table 3 also includes the information for several other industries where more than 50\% of import value was covered by the ITA, and industries such as business machines and equipment, and measuring, testing, and control instruments, where less than $50 \%$ of the import value was impacted by the ITA agreement. ${ }^{10}$

In Table 3 we show the average tariffs at the beginning of 1997, before the ITA was implemented, and in 2000, when it was concluded. Clearly, U.S. tariffs in these industries even before the ITA agreement were low: average tariffs were between 1-4\% in all industries, and zero or nearly so in computer accessories and semiconductors. This means that the ITA tariff cuts for the United States were correspondingly small. But remember that the ITA was a multilateral agreement, so that tariff cuts in the U.S. could be matched by equal or larger tariff cuts abroad. For firms sourcing their IT products from overseas locations, the tariffs cuts within the ITA could therefore have had a multiplied impact on lowering their import prices and costs, as we will argue in section 5. Yi (2002) formally models how in the presence of cross-border production networks like those so central to IT, trade-barrier reductions can trigger magnified and non-linear responses in prices (and trade volumes).

In addition to their potential impact on prices, multilateral tariff cuts under the ITA could expand the range of supplying countries, providing differentiated varieties of IT products. Recent literature has shown how to measure the product variety of imports, i.e., the "extensive margin" of trade (Feenstra, 1994; Hummels and Klenow, 2005; Broda and Weinstein, 2006). In the final column of Table 3 we show the growth in import varieties over 1996 - 2006 for each 5-digit Enduse category, reflecting the increasing number of supplying countries. Exactly how we calculate import variety will be explained below. For now, we just note that the increases in import variety for the

\footnotetext{
${ }^{10}$ Omitted from Table 3 are industries where less than $10 \%$ of imports are covered by the ITA.
} 
ITA products exceeded that for all other imports. This suggests the multilateral tariff cuts under the

ITA increased the range of supplying countries beyond variety increases in trade more generally.

\section{Measurement of Productivity Growth with International Trade}

We have seen in the previous section that tariffs on imported ICT products fell during the period covered by the ITA. In this section we describe how such declines in tariffs are incorporated into the measurement of total factor productivity (TFP) at an economy-wide level. In our exposition of the theory, we assume that productivity is measured for GDP as a whole even though, in practice, the available information only permits the private business portion of GDP to be included in the broad measure of productivity growth.

Our theoretical model extends the model of international trade and productivity of Diewert and Morrison (1986), which treats imports as intermediate inputs into the economy’s GDP function. Though such a uniform treatment for all imports might appear to ignore the significant representation of finished goods in U.S. imports, Diewert and Morrison argue that imports can all be treated as intermediate inputs in the GDP function because even finished good imports generally require domestically produced distribution services to get to final consumers. Modeling all imports as intermediate inputs into the GDP function is also reasonable for our purposes, because imported finished consumer goods are treated in just the same way as imported intermediates in the import price indexes, and any bias in those indexes have the same impact on the measurement of real GDP growth. ${ }^{11}$

\footnotetext{
${ }^{11}$ However investment goods that are imported directly by their final purchaser are deflated identically when they are part of imports ( $\mathrm{M}$ in the equation GDP $=\mathrm{C}+\mathrm{I}+\mathrm{G}+\mathrm{X}-\mathrm{M}$ ) and when they are part of investment (I), so the effects on $\mathrm{M}$ are canceled by the effects on I in calculations of real GDP. Therefore, including imported investment goods (such as an Airbus aircraft) as intermediate inputs in the GDP function causes a slight overstatement of the effect of mismeasured imports on estimates of real GDP. The overstatement of the effect on TFP caused by this treatment of imported investment goods is negligible, however, because over-estimation of real investment causes an overestimation of capital services on the input side of the real TFP calculation.
} 
Let there be $i=1, \ldots, M$ final goods, with quantities $q_{i}^{t} \geq 0$ and prices $p_{i}^{t}>0$. In addition, there are $i=1, \ldots, N$ exported outputs, with quantities $x_{i}^{t} \geq 0$ and international prices $p_{x i}^{t}>0$. For simplicity, we ignore taxes or subsidies on exports. Finally, there are also $\mathrm{i}=1, \ldots, \mathrm{N}$ imported intermediate inputs, but each of these come in $\mathrm{j}=1, \ldots, \mathrm{C}$ varieties indexed by the country of origin. So the import quantities are $\mathrm{m}_{\mathrm{ij}}^{\mathrm{t}} \geq 0$, with international prices $\mathrm{p}_{\mathrm{mij}}^{\mathrm{t}}>0$, ad valorem tariffs $\tau_{\mathrm{ij}}^{\mathrm{t}}$, and domestic prices $\mathrm{p}_{\mathrm{mij}}^{\mathrm{t}}\left(1+\tau_{\mathrm{ij}}^{\mathrm{t}}\right)$.

The vector of final goods and free-trade prices is denoted by $\mathrm{P}^{\mathrm{t}}=\left(\mathrm{p}^{\mathrm{t}}, \mathrm{p}_{\mathrm{x}}^{\mathrm{t}}, \mathrm{P}_{\mathrm{m}}^{\mathrm{t}}\right)$, and the quantities of these goods are $\mathrm{y}^{\mathrm{t}}=\left(\mathrm{q}^{\mathrm{t}}, \mathrm{x}^{\mathrm{t}}, \mathrm{m}^{\mathrm{t}}\right) \geq 0$. Further, the import tariffs are in the vector $\tau^{\mathrm{t}}$. Then the revenue function for the economy is:

$$
R^{t}\left(P^{t}, \tau^{t}, v^{t}\right) \equiv \max _{y^{t} \geq 0}\left\{\sum_{i=1}^{M} p_{i}^{t} q_{i}^{t}+\sum_{i=1}^{N} p_{x i}^{t} x_{i}^{t}-\sum_{i=1}^{N} \sum_{j=1}^{C} p_{m i j}^{t}\left(1+\tau_{i j}^{t}\right) m_{i j}^{t} \mid y^{t} \in S^{t}\left(v^{t}\right)\right\}
$$

where $S^{t}\left(v^{t}\right)$ is a convex technology set that depends on the country's endowment of primary factors $v^{t}$. We assume that $S^{t}\left(v^{t}\right)$ is strictly convex, so the maximum in (1) is well-defined. The superscript $t$ on the revenue function indicates that the technology can change over time.

The revenue function equals the total value added of all industries with tariffs included in intermediate input costs, which is the "production approach" measure of the economy's output. ${ }^{12}$ In contrast, tariffs are excluded from the cost of imports in the definition of GDP because the tariff revenue remains within the importing country. Let $X^{t}=\sum_{i=1}^{N} p_{x i}^{t} x_{i}^{t}$ denote the value of exports and let $\mathrm{M}^{\mathrm{t}}=\sum_{\mathrm{i}=1}^{\mathrm{N}} \sum_{\mathrm{j}=1}^{\mathrm{C}} \mathrm{p}_{\mathrm{mij}}^{\mathrm{t}} \mathrm{m}_{\mathrm{ij}}^{\mathrm{t}}$ denote the value of imports at duty-free prices. Using

\footnotetext{
${ }^{12}$ Assuming that tariffs are the only tax on products, $\mathrm{R}^{\mathrm{t}}\left(\mathrm{P}^{\mathrm{t}}+\mathrm{T}^{\mathrm{t}}, \mathrm{v}^{\mathrm{t}}\right)$ is the recommended measure of aggregate output and equation (3) below is the recommended "production approach" measure of GDP in the System of National Accounts or SNA (United Nations et al., 1993, paragraphs 6.235-6.237.) We use the SNA definition of valued added, not the BEA one. BEA defines total gross value-added to include tariffs and other taxes on products.
} 
the expenditure approach, nominal GDP is measured by:

$$
\mathrm{GDP}^{\mathrm{t}} \equiv \sum_{i=1}^{\mathrm{M}} \mathrm{p}_{i}^{\mathrm{t}} \mathrm{q}_{\mathrm{i}}^{\mathrm{t}}+\left(\mathrm{X}^{\mathrm{t}}-\mathrm{M}^{\mathrm{t}}\right)
$$

Substituting for $\mathrm{X}^{\mathrm{t}}$ and $\mathrm{M}^{\mathrm{t}}$, we can re-write nominal GDP as the function:

$$
G^{t}\left(P^{t}, \tau^{t}, v^{t}\right)=R^{t}\left(P^{t}, \tau^{t}, v^{t}\right)+\sum_{i=1}^{N} \sum_{j=1}^{C} P_{m i j}^{t} \tau_{i j}^{t} m_{i j}^{t},
$$

where the equality is obtained using the definition of the revenue function $R^{t}\left(P^{t}, \tau^{t}, v^{t}\right)$. Equation (3) states that nominal GDP equals the aggregate output $\mathrm{R}^{\mathrm{t}}\left(\mathrm{P}^{\mathrm{t}}, \tau^{\mathrm{t}}, \mathrm{v}^{\mathrm{t}}\right)$ plus tariff revenue.

To analyze the effect of tariff changes on the measure of nominal GDP, we use the GDP function in (3) to obtain the familiar optimality of free trade in a small open economy:

\section{Proposition 1}

Holding fixed $\mathrm{P}^{\mathrm{t}}$ and $\mathrm{v}^{\mathrm{t}}$, the value of GDP in (3) is maximized at $\tau^{\mathrm{t}}=0$.

Proof: Because the derivative of the revenue function with respect to $\tau_{\mathrm{ij}}^{\mathrm{t}}$ is $-\mathrm{p}_{\mathrm{mij}}^{\mathrm{t}} \mathrm{m}_{\mathrm{ij}}^{\mathrm{t}}$, it follows that the first derivative of the GDP function with respect to $\tau_{\mathrm{ij}}^{\mathrm{t}}$ is zero evaluated at $\tau_{\mathrm{ij}}^{\mathrm{t}}=0$. The second derivative is negative semi-definite because the revenue function is concave in import prices. It follows that $\tau^{\mathrm{t}}=0$ is a maximum. QED

This familiar result shows the optimality of zero tariffs in a small country, and has a very important implication for the measurement of productivity. Diewert (2006, p. 301), citing Jorgenson and Griliches (1972), observes that tariffs and similar taxes on intermediate inputs (such as excise taxes) should be included in input prices when measuring productivity change. The revenue function allows us to do this because it uses tariff-inclusive prices. We will show that even if "true" productivity change is zero, then total factor productivity as it is commonly measured will be positive when tariffs are reduced. 
To show this result we begin by defining "true" productivity. A very general formulation of productivity change, due originally to Caves, Christensen and Diewert (1982) and applied to an open economy setting by Diewert and Morrison (1986), Kohli (1990, 2004, 2005, 2006) and Diewert (2008), comes from defining productivity as the shift in the economy's revenue function while holding prices and factor endowments fixed. Depending on which period's prices and endowments are chosen, productivity growth is defined as either:

$$
A^{t-1} \equiv \frac{R^{t}\left(P^{t-1}, \tau^{t-1}, v^{t-1}\right)}{R^{t-1}\left(P^{t-1}, \tau^{t-1}, v^{t-1}\right)}, \text { or } A^{t} \equiv \frac{R^{t}\left(P^{t}, \tau^{t}, v^{t}\right)}{R^{t-1}\left(P^{t}, \tau^{t}, v^{t}\right)}
$$

These concepts of productivity change are not measurable because both the numerator of $\mathrm{A}^{\mathrm{t}-1}$ and the denominator of $\mathrm{A}^{\mathrm{t}}$ are unobservable. Yet their geometric mean can be measured, once we assume a specific form for the revenue function. In particular, suppose that the revenue function takes a nested form. In the first stage, for imported varieties $j \in J_{i} \subseteq\{1, \ldots, C\}$, we suppose that the revenue function in (1) is a CES function with elasticity $\sigma_{\mathrm{i}}$,

$$
\tilde{\mathrm{p}}_{\mathrm{mi}}^{\mathrm{t}}=\left[\sum_{\mathrm{j} \in \mathrm{J}_{\mathrm{i}}} \mathrm{b}_{\mathrm{ij}} \mathrm{p}_{\mathrm{mij}}^{\mathrm{t}}\left(1+\tau_{\mathrm{ij}}^{\mathrm{t}}\right)^{-\left(1-\sigma_{\mathrm{i}}\right)}\right]^{-1 /\left(1-\sigma_{\mathrm{i}}\right)}, \mathrm{i}=1, \ldots, \mathrm{N} .
$$

In the next section we will show how the import prices can be aggregated over supplying countries, obtaining $\tilde{\mathrm{p}}_{\mathrm{mi}}^{\mathrm{t}}$, but for now suppose that these aggregate import prices are available, and denote the vector of prices by $\widetilde{\mathrm{P}}^{\mathrm{t}} \equiv\left(\mathrm{p}^{\mathrm{t}}, \mathrm{p}_{\mathrm{x}}^{\mathrm{t}}, \widetilde{\mathrm{P}}_{\mathrm{m}}^{\mathrm{t}}\right)$. Then in the second stage, across goods and factors, we suppose that the revenue function is a translog function over the prices $\widetilde{\mathrm{P}}^{\mathrm{t}}$ and endowments. We further assume that the parameters multiplying these prices in the translog revenue function are stable over time, but the coefficients multiplying endowments are allowed 
to change over time, reflecting technological change. ${ }^{13}$ It follows from Diewert and Morrison (1986) that:

$$
\left(\mathrm{A}^{\mathrm{t}-1} \mathrm{~A}^{\mathrm{t}}\right)^{\mathrm{t} / 2}=\left(\frac{\mathrm{R}^{\mathrm{t}}}{\mathrm{R}^{\mathrm{t}-1}}\right) /\left[\mathrm{P}_{\mathrm{T}}\left(\widetilde{\mathrm{P}}^{\mathrm{t}-1}, \widetilde{\mathrm{P}}^{\mathrm{t}}, \mathrm{y}^{\mathrm{t}-1}, \mathrm{y}^{\mathrm{t}}\right) \mathrm{Q}_{\mathrm{T}}\left(\mathrm{v}^{\mathrm{t}-1}, \mathrm{v}^{\mathrm{t}}, \mathrm{w}^{\mathrm{t}-1}, \mathrm{w}^{\mathrm{t}}\right)\right]
$$

where $\mathrm{P}_{\mathrm{T}}\left(\widetilde{\mathrm{P}}^{\mathrm{t}-1}, \widetilde{\mathrm{P}}^{\mathrm{t}}, \mathrm{y}^{\mathrm{t}-1}, \mathrm{y}\right)$ is a Törnqvist price index over final goods, exports and imports, and $\mathrm{Q}_{\mathrm{T}}\left(\mathrm{w}^{\mathrm{t}-1}, \mathrm{w}^{\mathrm{t}}, \mathrm{v}^{\mathrm{t}-1}, \mathrm{v}^{\mathrm{t}}\right)$ is a Törnqvist quantity index over primary factors, with prices $\mathrm{w}^{\mathrm{t}-1}$ and $\mathrm{w}^{\mathrm{t}}$.

Equation (6) states that productivity growth can be measured by deflating the change in nominal revenue $\mathrm{R}^{\mathrm{t}}$ by its price deflator $\mathrm{P}_{\mathrm{T}}$, then comparing the estimate of real revenue growth to the growth in primary factors $\mathrm{Q}_{\mathrm{T}}$. The Törnqvist price index appearing in (6) is defined as:

$$
\begin{aligned}
& \ln \mathrm{P}_{\mathrm{T}}\left(\widetilde{\mathrm{P}}^{\mathrm{t}-1}, \widetilde{\mathrm{P}}^{\mathrm{t}}, \mathrm{y}^{\mathrm{t}-1}, \mathrm{y}^{\mathrm{t}}\right) \\
& \equiv \sum_{\mathrm{i}=1}^{\mathrm{M}}\left(\frac{1}{2}\right)\left(\frac{\mathrm{p}_{\mathrm{i}}^{\mathrm{t}-1} \mathrm{q}_{\mathrm{i}}^{\mathrm{t}-1}}{\mathrm{R}^{\mathrm{t}-1}}+\frac{\mathrm{p}_{\mathrm{i}}^{\mathrm{t}} \mathrm{q}_{\mathrm{i}}^{\mathrm{t}}}{\mathrm{R}^{\mathrm{t}}}\right) \ln \left(\frac{\mathrm{p}_{\mathrm{i}}^{\mathrm{t}}}{\mathrm{p}_{\mathrm{i}}^{\mathrm{t}-1}}\right)+\sum_{\mathrm{i}=1}^{\mathrm{N}}\left(\frac{1}{2}\right)\left(\frac{\mathrm{p}_{\mathrm{xi}}^{\mathrm{t}-1} \mathrm{x}_{\mathrm{i}}^{\mathrm{t}-1}}{\mathrm{R}^{\mathrm{t}-1}}+\frac{\mathrm{P}_{\mathrm{xi}}^{\mathrm{t}} \mathrm{x}_{\mathrm{i}}^{\mathrm{t}}}{\mathrm{R}^{\mathrm{t}}}\right) \ln \left(\frac{\mathrm{p}_{\mathrm{xi}}^{\mathrm{t}}}{\mathrm{p}_{\mathrm{xi}}^{\mathrm{t}-1}}\right) \\
& -\sum_{\mathrm{i}=1}^{\mathrm{N}}\left(\frac{1}{2}\right)\left(\frac{\sum_{\mathrm{j}=1}^{\mathrm{C}} \mathrm{P}_{\mathrm{mij}}^{\mathrm{t}-1}\left(1+\tau_{\mathrm{ij}}^{\mathrm{t}-1}\right) \mathrm{m}_{\mathrm{ij}}^{\mathrm{t}-1}}{\mathrm{R}^{\mathrm{t}-1}}+\frac{\sum_{\mathrm{j}=1}^{\mathrm{C}} \mathrm{p}_{\mathrm{mij}}^{\mathrm{t}}\left(1+\tau_{\mathrm{ij}}^{\mathrm{t}}\right) \mathrm{m}_{\mathrm{ij}}^{\mathrm{t}}}{\mathrm{R}^{\mathrm{t}}}\right) \ln \left(\frac{\widetilde{\mathrm{P}}_{\mathrm{mi}}^{\mathrm{t}}}{\widetilde{\mathrm{P}}_{\mathrm{mi}}^{\mathrm{t}-1}}\right)
\end{aligned}
$$

Note that the weights used to sum over domestic goods, exports and imports in (7) add up to unity, and that imports receive a negative weight since they are inputs.

We can now compare "true" productivity growth in (6) to what is typically measured. The treatment of tariffs in conventional estimates of aggregate TFP differs from their treatment in (5) because nominal output is measured by $\mathrm{GDP}^{\mathrm{t}}$, not $\mathrm{R}^{\mathrm{t}}$, and because import prices are measured without tariffs in the index used to deflate imports. That is, conventional estimates of

\footnotetext{
${ }^{13}$ The coefficients multiplying both prices and endowments are also allowed to change. The key restriction imposed by this assumption is that the coefficients $\gamma_{\mathrm{ij}}$ that appear in $\sum_{\mathrm{ij}} \gamma_{\mathrm{ij}} \ln \widetilde{\mathrm{P}}_{\mathrm{i}} \ln \widetilde{\mathrm{P}}_{\mathrm{j}}$, which is one component of the translog revenue function, cannot change over time.
} 
aggregate TFP are computed as:

$$
\mathrm{TFP}^{\mathrm{t}} \equiv\left(\frac{\mathrm{G}^{\mathrm{t}}}{\mathrm{G}^{\mathrm{t}-1}}\right) /\left[\mathrm{P}_{\mathrm{E}}\left(\mathrm{P}^{\mathrm{t}-1}, \mathrm{P}^{\mathrm{t}}, \mathrm{y}^{\mathrm{t}-1}, \mathrm{y}^{\mathrm{t}}\right) \mathrm{Q}_{\mathrm{E}}\left(\mathrm{w}^{\mathrm{t}-1}, \mathrm{w}^{\mathrm{t}}, \mathrm{v}^{\mathrm{t}-1}, \mathrm{v}^{\mathrm{t}}\right)\right]
$$

where $G^{t} \equiv G^{t}\left(P^{t}, \tau^{t}, v^{t}\right)$ is nominal GDP, and $P_{E}\left(P^{t-1}, P^{t}, y^{t-1}, y^{t}\right)$ is an exact GDP deflator over prices of final domestic demand, exports, and duty-free imports. Notice that if the functional form for these price indexes is exact for the underlying revenue function (as is the case for the Törnqvist index, which is exact for the translog revenue function), and if tariffs are zero, then aggregate TFP in (8) is identical to "true” productivity growth in (6). However, TFP will differ from "true" productivity when tariffs are non-zero or when the price indexes used in (8) are not exact for the underlying revenue function, as is the case for the U.S. In particular, the GDP price deflator $\mathrm{P}_{\mathrm{E}}\left(\mathrm{P}^{\mathrm{t}-1}, \mathrm{P}^{\mathrm{t}}, \mathrm{y}^{\mathrm{t}-1}, \mathrm{y}{ }^{\mathrm{t}}\right)$ appearing in (8) is constructed by the BEA as a Fisher Ideal index over components of the CPI, PPI and export and import price indexes obtained from BLS. The export and import prices are Laspeyres indexes at the 5-digit Enduse level, which are duty-free.

To understand the impact of tariffs on "true" versus measured TFP, notice that "true" productivity in (6) has tariffs appearing in both the numerator (as arguments of the revenue function) and the denominator (the Törnqvist price index is tariff-inclusive). In contrast, measured TFP in (8) excludes tariffs from both the numerator (think of GDP as $\mathrm{C}+\mathrm{I}+\mathrm{G}+\mathrm{X}-\mathrm{M}$, with imports measured at duty-free prices) and the denominator (since the prices in the import indexes from BLS are duty-free). So the construction of conventional TFP in (8) seems to be consistent in its treatment of tariffs. But despite this apparent consistency, the quantities of outputs and inputs are chosen at tariff-distorted prices in (8) and will respond to changes in tariffs. The impact of these quantity responses is shown by the following result: 


\section{Proposition 2}

Assume that technology, prices and endowments do not change between periods, so that $\mathrm{S}^{\mathrm{t}-1}=\mathrm{S}^{\mathrm{t}}$, $\mathrm{P}^{\mathrm{t}-1}=\mathrm{P}^{\mathrm{t}}$, and $\mathrm{v}^{\mathrm{t}-1}=\mathrm{v}^{\mathrm{t}}$. Then reducing tariffs from $\tau^{\mathrm{t}-1} \neq 0$ to $\tau^{\mathrm{t}}=0$ will lead to $\operatorname{TFP}^{\mathrm{t}}>1$ in (8), even though $\left(\mathrm{A}^{\mathrm{t}-1} \mathrm{~A}^{\mathrm{t}}\right)^{1 / 2}=1 \mathrm{in}(6)$, indicating that there is no "true" productivity change.

Proof: The assumption that $\mathrm{S}^{\mathrm{t}-1}=\mathrm{S}^{\mathrm{t}}$ implies $\left(\mathrm{A}^{\mathrm{t}-1} \mathrm{~A}^{\mathrm{t}}\right)^{1 / 2}=1$ in (6). Further assuming that $\mathrm{P}^{\mathrm{t}-1}=$ $P^{t}$ and $v^{t-1}=v^{t}$ means that $P_{E}=Q_{E}=1$. From these assumptions we have $G^{t-1}\left(P^{t-1}, \tau^{t-1}, v^{t-1}\right)=$ $\mathrm{G}^{\mathrm{t}}\left(\mathrm{P}^{\mathrm{t}}, \tau^{\mathrm{t}-1}, \mathrm{v}^{\mathrm{t}}\right)$, which is not being maximized because $\tau^{\mathrm{t}-1} \neq 0$. From Proposition 1 , reducing tariffs to zero raises GDP, so $G^{t}\left(P^{t}, 0, v^{t}\right)>G^{t}\left(P^{t}, \tau^{t-1}, v^{t}\right)$ and $T F P^{t}>1$ in (8). QED

Proposition 2 states that the efficiency gain from eliminating tariffs - which is a movement around the production possibilities frontier - will incorrectly be attributed to TFP growth as measured by (8). The mismeasurement in TFP due to tariff reductions is of the secondorder, since the efficiency gain from eliminating tariffs is of the second-order. The following proposition shows that a similar result holds for changes in the terms of trade in the presence of tariffs:

\section{Proposition 3}

Assume that technology and endowments do not change between periods, so that $\mathrm{S}^{\mathrm{t}-1}=\mathrm{S}^{\mathrm{t}}$ and $\left(A^{t-1} A^{t}\right)^{1 / 2}=1$ in (6). Then $\operatorname{TFP}^{t} \neq 1$ in (8) due to changing prices only if $\tau^{t-1} \neq 0$ or $\tau^{t} \neq 0$.

The proof is immediate, since when $\tau^{\mathrm{t}-1}=\tau^{\mathrm{t}}=0$, then measured TFP in (8) is identical to "true" productivity in (6), which is unity regardless of any change in price. Thus, a change in the terms of trade has an impact on measured TFP only if tariffs are non-zero. But if tariffs are small, then this impact is correspondingly small. This result confirms the same finding by Kim and Ruhl (2008) for a one-sector economy. 
For the United States and other industrial countries, tariffs and changes in tariffs — such as occurred under the ITA — are low. Thus, we might expect that the impact of the ITA and other tariff reductions on measured TFP is small. However, an indirect effect of eliminating tariffs under the ITA is the entry of new countries into supplying ICT products. Provided that the new countries are supplying differentiated products, the resulting fall in the CES indexes of import prices leads to a mismeasurement of TFP that is not second-order. Furthermore, the formula bias from aggregating export and import prices with Laspeyres index formulas could also significantly distort measured TFP. As noted above, the BEA uses 5-digit Enduse export and import prices indexes that it obtains from BLS. These are Laspeyres indexes, so we denote them by $\mathrm{P}_{\mathrm{xiL}}^{\mathrm{t}-1, \mathrm{t}}$ and $\mathrm{P}_{\mathrm{miL}}^{\mathrm{t}-1, \mathrm{t}}$. The BEA uses a Fisher formula to aggregate detailed indexes from BLS to obtain the GDP deflator in (8). The difference between the Fisher and the Törnqvist formulas is negligible, so for convenience we will write the GDP deflator as the Törnqvist formula over the domestic prices and Laspeyres export and import indexes: ${ }^{14}$

$$
\begin{aligned}
& \ln P_{E}\left(P^{t-1}, P^{t}, y^{t-1}, y^{t}\right) \\
& \equiv \sum_{i=1}^{M}\left(\frac{1}{2}\right)\left(\frac{p_{i}^{t-1} q_{i}^{t-1}}{G^{t-1}}+\frac{p_{i}^{t} q_{i}^{t}}{G^{t}}\right) \ln \left(\frac{p_{i}^{t}}{p_{i}^{t-1}}\right)+\sum_{i=1}^{N}\left(\frac{1}{2}\right)\left(\frac{p_{x i}^{t-1} x_{i}^{t-1}}{G^{t-1}}+\frac{p_{x i}^{t} x_{i}^{t}}{G^{t}}\right) \ln P_{x i L}^{t-1, t} \\
& -\sum_{i=1}^{N}\left(\frac{1}{2}\right)\left(\frac{\sum_{j=1}^{\mathrm{C}} p_{m i j}^{t-1} m_{i j}^{t-1}}{G^{t-1}}+\frac{\sum_{j=1}^{C} p_{m i j}^{t} m_{i j}^{t}}{G^{t}}\right) \ln P_{m i L}^{t-1, t} .
\end{aligned}
$$

For convenience, we also suppose that a Törnqvist formula is used for $Q_{E}\left(w^{t-1}, w^{t}, v^{t-1}, v^{t}\right)$ in (8), which is the quantity index of primary factors, just as in (6).

Comparing (6)-(7) with (8)-(9), we see that the difference between measured and "true" TFP growth is:

\footnotetext{
${ }^{14}$ Note that we are ignoring any issues that arise from the CPI components used in the GDP price deflator.
} 


$$
\begin{aligned}
& \ln T F P^{t}-\ln \left(A^{t-1} A^{t}\right)^{1 / 2}=\ln \left(\frac{G^{t}}{R^{t}}\right)-\ln \left(\frac{G^{t-1}}{R^{t-1}}\right) \\
& +\sum_{i=1}^{N}\left[\left(\frac{1}{2}\right)\left(\frac{p_{x i}^{t-1} x_{i}^{t-1}}{R^{t-1}}+\frac{p_{x i}^{t} x_{i}^{t}}{R^{t}}\right) \ln \left(\frac{p_{x i}^{t}}{p_{x i}^{t-1}}\right)-\left(\frac{1}{2}\right)\left(\frac{p_{x i}^{t-1} x_{i}^{t-1}}{G^{t-1}}+\frac{p_{x i}^{t} x_{i}^{t}}{G^{t}}\right) \ln P_{x i L}^{t-1, t}\right] \\
& -\sum_{i=1}^{N}\left(\frac{1}{2}\right)\left(\frac{\sum_{j=1}^{\mathrm{C}} p_{m i j}^{t-1}\left(1+\tau_{i j}^{t-1}\right) m_{i j}^{t-1}}{R^{t-1}}+\frac{\sum_{j=1}^{C} p_{m i j}^{t}\left(1+\tau_{i j}^{t}\right) m_{i j}^{t}}{R^{t}}\right) \ln \left(\frac{\tilde{p}_{m i}^{t}}{\tilde{p}_{m i}^{t-1}}\right) \\
& +\sum_{i=1}^{N}\left(\frac{1}{2}\right)\left(\frac{\sum_{j=1}^{\mathrm{C}} p_{m i j}^{t-1} m_{i j}^{t-1}}{G^{t-1}}+\frac{\sum_{j=1}^{\mathrm{C}} p_{m i j}^{t} m_{i j}^{t}}{G^{t}}\right) \ln P_{m i L}^{t-1, t} .
\end{aligned}
$$

To interpret the first line of (10), notice that $\mathrm{G}^{\mathrm{t}}$ and $\mathrm{R}^{\mathrm{t}}$ differ only by tariff revenue, as in (3). For the U.S. economy as a whole, tariff revenue relative to GDP is very small, and so is the difference between $\mathrm{G}^{\mathrm{t}}$ and $\mathrm{R}^{\mathrm{t}}$, so these first terms are small. The second bracketed term depends on the difference between the "true" export prices $\left(\mathrm{p}_{\mathrm{xi}}^{\mathrm{t}} / \mathrm{p}_{\mathrm{xi}}^{\mathrm{t}-1}\right)$ and Laspeyres index of export prices. If the Laspeyres index overstates the export prices, as we shall find, that tends to make measured TFP less than "true" productivity. The reverse occurs on the import side, where upward bias in the Laspeyres import prices as compared to the "true" prices $\left(\tilde{\mathrm{p}}_{\mathrm{mi}}^{\mathrm{t}} / \tilde{\mathrm{p}}_{\mathrm{mi}}^{\mathrm{t}-1}\right)$ leads to an upward bias in measured TFP. We show in the following sections that the differences between the “true” prices $\left(\tilde{\mathrm{p}}_{\mathrm{mi}}^{\mathrm{t}} / \tilde{\mathrm{p}}_{\mathrm{mi}}^{\mathrm{t}-1}\right)$ and the Laspeyres indexes can be substantial, especially for ICT products, while the differences on the export side is not as large; as a result, the combined effect is an upward bias in the measurement of TFP.

\section{Measurement of International Prices}

The International Price Program (IPP) of the BLS uses monthly prices for imports and exports collected from firms to construct import and export prices indexes by means of a 
Laspeyres formula. We have the detailed monthly prices for September 1993 -December 2006, together with an (incomplete) set of the value weights used in the BLS indexes, as discussed in the Appendix. From these data we replicate the construction of BLS's Laspeyres indexes, and then improve on these methods by constructing Törnqvist price indexes.

Suppose that within Enduse industry $\mathrm{i}$ and month $\mathrm{t}$, a set $\mathrm{J}_{\mathrm{i}}^{\mathrm{t}}$ of price quotes is available. In the previous section we used $\mathrm{J}_{\mathrm{i}}^{\mathrm{t}}$ to denote countries exporting good i to the U.S., but more generally this set denotes all available prices by country, firm, and item-level products within the industry i. The Laspeyres import price index constructed by BLS is then:

$$
\mathrm{P}_{\mathrm{miL}}^{0, \mathrm{t}} \equiv \sum_{\mathrm{j} \in \mathrm{J}_{\mathrm{i}}^{\mathrm{t}}} \mathrm{w}_{\mathrm{mi}}^{0}\left(\frac{\mathrm{p}_{\mathrm{mij}}^{\mathrm{t}}}{\mathrm{p}_{\text {mij }}^{0}}\right),
$$

where $\mathrm{p}_{\mathrm{mi}}^{\mathrm{t}}$ is the duty-free price of import $\mathrm{i}$ in month $\mathrm{t} ; \mathrm{p}_{\mathrm{mi}}^{0}$ is the price of item $\mathrm{i}$ in a base year 0 , and $\mathrm{w}_{\mathrm{mi}}^{0}$ is the annual import share is a base year 0 , with $\sum_{\mathrm{i}} \mathrm{w}_{\mathrm{mi}}^{0}=1$. Since (11) refers to the cumulative price increase from the base period 0 to month $t$, the month-to-month price change is obtained as the ratio of such long-term indexes:

$$
\mathrm{P}_{\mathrm{miL}}^{\mathrm{t}-1, \mathrm{t}} \equiv \mathrm{P}_{\mathrm{miL}}^{0, \mathrm{t}} / \mathrm{P}_{\mathrm{miL}}^{0, \mathrm{t}-1}
$$

Analogous formulas apply on the export side.

Consider now the "true" import prices, $\widetilde{\mathrm{p}}_{\mathrm{mi}}^{\mathrm{t}}$. In the previous section we assumed that the revenue function was CES across the set of countries selling each good $i$. In that case, the import prices $\widetilde{\mathrm{p}}_{\mathrm{mi}}^{\mathrm{t}}$ should be obtained using an index formula that is exact for the CES function. To develop that index, suppose first that the set of countries $\mathrm{j}$ selling good i does not change, and denote that set by $\mathrm{j} \in \mathrm{J}_{\mathrm{i}}$. Then the ratio of CES price aggregates can be expressed as: 


$$
P_{m i G}^{t-1, t} \equiv \prod_{j \in J_{i}}\left(\frac{p_{m i j}^{t}\left(1+\tau_{i j}^{t}\right)}{P_{m i j}^{t-1}\left(1+\tau_{i j}^{t-1}\right)}\right)^{w_{m i j}^{t}}
$$

where $\mathrm{P}_{\mathrm{miG}}^{\mathrm{t}-1, \mathrm{t}}$ is the geometric index due to Sato (1977) and Vartia (1977), and uses the weights $\mathrm{w}_{\mathrm{mij}}^{\mathrm{t}}$ which are the logarithmic mean of the import shares in periods $\mathrm{t}-1$ and $\mathrm{t}$, for good $\mathrm{i}$ and country $\mathrm{j}$, constructed from the expenditure shares:

$$
\mathrm{s}_{\mathrm{mij}}^{\mathrm{t}}=\frac{\mathrm{p}_{\mathrm{mij}}^{\mathrm{t}}\left(1+\tau_{\mathrm{ij}}^{\mathrm{t}}\right) \mathrm{m}_{\mathrm{ij}}^{\mathrm{t}}}{\sum_{\mathrm{i} \in \mathrm{J}_{\mathrm{i}}} \mathrm{p}_{\mathrm{mij}}^{\mathrm{t}}\left(1+\tau_{\mathrm{ij}}^{\mathrm{t}}\right) \mathrm{m}_{\mathrm{ij}}^{\mathrm{t}}} \text {, with } \mathrm{w}_{\text {mij }}^{\mathrm{t}} \equiv\left(\frac{\mathrm{s}_{\mathrm{mij}}^{\mathrm{t}}-\mathrm{s}_{\mathrm{mij}}^{\mathrm{t}-1}}{\ln \mathrm{s}_{\mathrm{mij}}^{\mathrm{t}}-\ln \mathrm{s}_{\mathrm{mij}}^{\mathrm{t}-1}}\right) / \sum_{\mathrm{i} \in \mathrm{J}_{\mathrm{i}}}\left(\frac{\mathrm{s}_{\mathrm{mij}}^{\mathrm{t}}-\mathrm{s}_{\mathrm{mij}}^{\mathrm{t}-1}}{\ln \mathrm{s}_{\mathrm{mij}}^{\mathrm{t}}-\ln \mathrm{s}_{\text {mij }}^{\mathrm{t}-1}}\right) \text {. }
$$

That is, the Sato-Vartia index is a geometric mean over the import price ratios, computed over the countries that are supplying the import good in both periods.

As new supplying countries sell good $i$, we need to extend the Sato-Vartia formula to incorporate the new (and also any disappearing) countries. That formula is available from Feenstra (1994). Suppose that the set of countries supplying product $\mathrm{i}$ in period $\mathrm{t}, \mathrm{j} \in \mathrm{J}_{\mathrm{i}}^{\mathrm{t}}$, has a non-empty intersection with period $\mathrm{t}-1, \mathrm{~J}_{\mathrm{i}} \equiv \mathrm{J}_{\mathrm{i}}^{\mathrm{t}-1} \cap \mathrm{J}_{\mathrm{i}}^{\mathrm{t}} \neq \varnothing$. Then define the terms $\lambda_{\mathrm{mi}}^{\mathrm{t}-1}$ and $\lambda_{\mathrm{mi}}^{\mathrm{t}}$ as the value of imports in periods $\mathrm{t}-1$ and $\mathrm{t}$ from countries supplying product $\mathrm{i}$ in both these periods, relative to the total imports of product $\mathrm{i}$ in each period:

$$
\lambda_{m i}^{t} \equiv \frac{\sum_{j \in J_{i}} p_{m i j}^{t} m_{i j}^{t}}{\sum_{j \in J_{i}^{t}} p_{m i j}^{t} m_{i j}^{t}} \leq 1 .
$$

The terms $\lambda_{\mathrm{mi}}^{\mathrm{t}} \leq 1$ can be interpreted as the period t expenditure on the goods in the set $J_{i}$ relative to total import expenditure on good $i$. Alternatively, this can be interpreted as one minus the share of period t expenditure on "new" selling countries (not in the set $J_{i}$ ). When there is a greater number of new selling countries in period t, this will lower the value of $\lambda_{\text {mi }}^{t}$. Then the 
ratio of CES price aggregates can be expressed as:

$$
\left(\frac{\widetilde{\mathrm{p}}_{\mathrm{mi}}^{\mathrm{t}}}{\tilde{\mathrm{p}}_{\mathrm{mi}}^{\mathrm{t}-1}}\right)=\mathrm{P}_{\mathrm{miG}}^{\mathrm{t}-1, \mathrm{t}}\left(\frac{\lambda_{\mathrm{mi}}^{\mathrm{t}}}{\lambda_{\mathrm{mi}}^{\mathrm{t}-1}}\right)^{1 /\left(\sigma_{\mathrm{i}}-1\right)},
$$

where $\mathrm{P}_{\mathrm{miG}}^{\mathrm{t}-1, \mathrm{t}}$ is again the geometric index due to Sato (1977) and Vartia (1977). As new

supplying countries sell more, then $\lambda_{\text {mi }}^{t}$ falls and so does the effective price in (16), by an amount that depends on the elasticity of substitution $\sigma_{i}$.

When applying equations (13) - (16) to the BLS price data, several issues arise. First, a true monthly Sato-Vartia price index $\mathrm{P}_{\mathrm{miG}}^{\mathrm{t}-1, \mathrm{t}}$ would require the use of monthly trade weights for imports. In practice the monthly trade weights are too volatile to be reliable, so we have instead used annual trade weights combined with monthly data on the import and export prices, to construct geometric indexes. The formula for the import index $\mathrm{P}_{\mathrm{miG}}^{\mathrm{t}-1, \mathrm{t}}$ is still given by (13)-(14), but now $\mathrm{w}_{\text {mij }}^{\mathrm{t}}$ reflects the annual import shares for Enduse industry i, which do not vary across months. The geometric indexes was are constructing could equally well be called Törnqvist - as we shall do - since with annual data there is no difference between the constant monthly values for $\mathrm{s}_{\mathrm{mij}}^{\mathrm{t}-1}=\mathrm{s}_{\mathrm{mij}}^{\mathrm{t}}$ and the weights $\mathrm{w}_{\mathrm{mij}}^{\mathrm{t}}$ in (14). ${ }^{15}$

Second, the import values used to construct the $\lambda$-values in (15) are also annual, and are taken from Harmonized System (HS) trade data. To apply these annual HS data to equations (15) and (16), let h denote a 10-digit HS good and $\mathrm{J}_{\mathrm{h}}^{\mathrm{t}}$ denote the set of countries exporting that good to the U.S. in any month within the year. Then $\mathrm{J}_{\mathrm{h}} \equiv \mathrm{J}_{\mathrm{h}}^{1989} \cap \mathrm{J}_{\mathrm{h}}^{\mathrm{t}}$ is the intersection of that set over

\footnotetext{
${ }^{15}$ Normally the Törnqvist index uses the simple averages $\left(\mathrm{s}_{\mathrm{mij}}^{\mathrm{t}-1}+\mathrm{s}_{\mathrm{mij}}^{\mathrm{t}}\right) / 2$ for weights, but $\mathrm{s}_{\mathrm{mij}}^{\mathrm{t}-1}=\mathrm{s}_{\text {mij }}^{\mathrm{t}}$ when using annual data. Then letting $\mathrm{s}_{\mathrm{mij}}^{\mathrm{t}-1} \rightarrow \mathrm{s}_{\mathrm{mij}}^{\mathrm{t}}$ in (16), we have $\mathrm{w}_{\mathrm{mij}}^{\mathrm{t}} \rightarrow \mathrm{s}_{\mathrm{mij}}^{\mathrm{t}}$, as can be shown using L'Hopitals rule.
} 
year t and 1989, which we use as the base year. We construct the $\lambda$-ratios in two steps: (a) we use (15) to construct $\left(\lambda_{m h}^{t} / \lambda_{m h}^{t-1}\right)$ for each HS product h, raising these to the power $1 /\left(\sigma_{h}-1\right)$, to reflect the elasticity of substitution between varieties coming from different countries; ${ }^{16}$ (ii) then we take the geometric mean across products $h \in \mathrm{H}_{\mathrm{i}}$ within an Enduse industry i:

$$
\Lambda_{\mathrm{mi}}^{\mathrm{t}} \equiv \prod_{\mathrm{h} \in \mathrm{H}_{\mathrm{i}}}\left(\lambda_{\mathrm{mh}}^{\mathrm{t}} / \lambda_{\mathrm{mh}}^{\mathrm{t}-1}\right)^{\mathrm{w}_{\mathrm{mhi}}^{\mathrm{t}} /\left(\sigma_{\mathrm{h}}-1\right)}
$$

Note that (17) is an inverse measure of import variety, because having new supplying countries will lead to a lower value in (17). In Table 3 we reported the negative of the log growth rate of $\Lambda_{\text {mi }}^{\mathrm{t}}$, which is the growth in import variety - adjusted by the elasticities of substitution - for each 5-digit Enduse industry. Finally, in (16) the Törnqvist index $\mathrm{P}_{\mathrm{miG}}^{\mathrm{t}-1, \mathrm{t}}$ is multiplied by $\Lambda_{\mathrm{mi}}^{\mathrm{t}}$ to obtain the price index corrected for variety.

Having obtained the import price indexes for each 5-digit Enduse industry, we do the same for exports, but in that case there is no correction for variety. We denote the Törnqvist export price indexes by $\mathrm{P}_{\mathrm{xiG}}^{\mathrm{t}-1, \mathrm{t}}$, which are used in place of $\left(\mathrm{p}_{\mathrm{xi}}^{\mathrm{t}} / \mathrm{p}_{\mathrm{xi}}^{\mathrm{t}-1}\right)$ in (10). The import and export price indexes are constructed for all 5-digit Enduse industries from September 1993 December 2006. In Figures 1 and 2 we displayed the terms of trade constructed from the Laspeyres and Törnqvist indexes for aggregate export and import price indexes. In Figure 3-10 we show the import and export indexes for the various ICT industries, normalized to 100 in September 1993 (except for the variety adjustment, which begins in 1990). Since the price indexes are very close in the early part of our sample, we start these graphs at January 1996.

In Figure 3 we show the BLS, Laspeyres and Törnqvist indexes for imports of Computers (Enduse 21300), with the adjustments for tariffs and variety. Our Laspeyres indexes differs only

\footnotetext{
${ }^{16}$ We use the elasticities of substitution estimated by Broda and Weinstein (2006).
} 
slightly from the published BLS price indexes, due to missing data and concordances that are not fully accurate, but the differences seem small enough to proceed. The Törnqvist index is about 7 percentage points below the Laspeyres by the end of the sample, and further adjustments for tariffs are very small. The impact of variety is to reduce the price index by a factor of 0.99 in 1996 and 0.90 in 2006, for an 8\% decline in the price index between those years. On the export side, in Figure 4 the BLS index, Laspeyres and Törnqvist are all very close, deviating only slightly over the sample period.

In Figure 5 we show the import price indexes for Computer Accessories (Enduse 21301). In this case the Törnqvist index in about 9 percentage points below the Laspeyres by the end of the sample. Further adjustment for tariffs and variety are small, , so that the Törnqvist index inclusive of tariffs and variety is 12 percentage points below the Laspeyres by December 2006 . For exports in Figure 6, the Törnqvist index has a relatively large drop in June 1998, which appears much more muted in the BLS index and the Laspeyres because those indexes are using base-period weights rather and current weights, and use an arithmetic mean formula (11) rather than the geometric mean (15).

Turning to Semiconductors (Enduse 3120) in Figures 7 and 8, for imports we again see that the Törnqvist index is about 13 percentage points below the Laspeyres by the end of the period. The impact of variety is significant, reducing the price index by a factor of 0.97 in 1996 and 0.77 in 2006, for a $10 \%$ decline in the price index due to variety in those years. For exports, we see that the Törnqvist index lies substantially below the Laspeyres index. This ranking of export price indexes was also found in Alterman, Diewert and Feenstra (1999). As they explain, it can be understood as resulting from technological improvement in the supply of exports, leading to higher quantities and falling prices along the foreign demand curve. So the export 
price index reflects substitution along foreign demand curves, and therefore the Laspeyres index overstates the increase in prices, just as the import price index reflects substitution along U.S. demand curves.

Finally, in Figures 9 and 10 we show the indexes for Telecommunications (Enduse 21400). In this case there was a significant fall in tariffs over 1996-1999. The variety adjustment is especially substantial, leading to a reduction in the Törnqvist index by a factor of 0.93 in both 1996 and 1999 and accelerating to 0.67 in 2006. On the export side we see that the Törnqvist index is below the Laspeyres, which is the same pattern that occurred in Semiconductors and in the later periods for Computer Accessories.

To summarize the results from these four ICT industries, in every case the Törnqvist index for imports is considerably below the Laspeyres by the end of the sample period, whereas for exports the indexes differed significantly in only two cases. That means the impact of the mismeasurement of import prices will have a greater impact on TFP - leading to an upward bias

- than the mismeasurement of export prices. In addition, there is a further impact of falling tariffs and rising variety on reducing the import price index. These additional impacts appear to be small in the Figures, but as we show in the next section, even small reductions in tariffs under the ITA have considerable impact on both prices and variety.

\section{Impact of the ITA on Import Prices and Variety}

To determine how the tariffs cuts under the ITA affected import prices, we construct a tariff index for industry $\mathrm{i}$, denoted by $\operatorname{Tar}_{\mathrm{i}}^{\mathrm{t}-1, \mathrm{t}}$, as:

$$
\operatorname{Tar}_{\mathrm{i}}^{\mathrm{t}-1, \mathrm{t}}=\prod_{\mathrm{j} \in \mathrm{J}_{\mathrm{i}}}\left(\frac{1+\tau_{\mathrm{ij}}^{\mathrm{t}}}{1+\tau_{\mathrm{ij}}^{\mathrm{t}-1}}\right)^{\mathrm{w}_{\mathrm{mij}}^{\mathrm{t}}} .
$$


In addition, we also construct a geometric index of exchange rates in Enduse industry i,

$\operatorname{Exch}_{\mathrm{i}}^{\mathrm{t}-1, \mathrm{t}}$, which is a weighted average of the exchange rate times the producer price indexes

(PPI) for U.S. trading partners. In this index we start with nominal exchange rates times the PPI for each country, average these across source countries for U.S. imports (using import country weights), and then aggregate these across commodities again using the geometric formula (with import commodity weights).

The various cumulated indexes are denoted by $\mathrm{P}_{\mathrm{miG}}^{0, \mathrm{t}}, \mathrm{P}_{\mathrm{xiG}}^{0, \mathrm{t}}, \operatorname{Tar}_{\mathrm{i}}^{0, \mathrm{t}}$ and $\operatorname{Exch}_{\mathrm{i}}^{0, \mathrm{t}}$. As noted above, to extend these variables beyond December 1999, we use the published Laspeyres import and exports price from BLS to extend $\mathrm{P}_{\mathrm{miG}}^{0, \mathrm{t}}$ and $\mathrm{P}_{\mathrm{xiG}}^{0, \mathrm{t}}$ to December 2006. Using these indexes, we run the following pass-through regression:

$$
\ln \mathrm{P}_{\mathrm{miG}}^{0, \mathrm{t}}=\alpha_{\mathrm{j} 0}+\sum_{\mathrm{k}=1}^{3} \alpha_{\mathrm{k}} \delta_{\mathrm{k}}^{\mathrm{t}}+\beta \ln \operatorname{Tar}_{\mathrm{i}}^{0, \mathrm{t}}+\sum_{\ell=0}^{6} \beta_{\ell} \ln \operatorname{Exch}_{\mathrm{i}}^{0, \mathrm{t}-\ell}+\gamma \mathrm{Z}_{\mathrm{i}}^{\mathrm{t}}+\varepsilon_{\mathrm{it}} \text {, }
$$

where: $\alpha_{\mathrm{i} 0}$ is a fixed-effect for each industry, and $\delta_{\mathrm{k}}^{\mathrm{t}}$ are three indicator variables for the stages

of the ITA (i.e. July 1997, January 1998 and January 1999) and $\mathrm{Z}_{\mathrm{i}}^{\mathrm{t}}$ denotes additional control variables. The prices of competing products also belong in regressions of this type, and we include the U.S. export prices $\mathrm{P}_{\mathrm{xiG}}^{0, \mathrm{t}}$ in industry i for this purpose, which is the first control. In addition, Bergin and Feenstra (2007) have recently shown that the share of imports coming from countries with fixed exchange rates, and its interaction with the exchange rate, add explanatory power to pass-through regressions for the U.S., so we include those variables too.

The results from this pass-through regression are shown in Table 4. The first regression is run over those industries where $100 \%$ of the import commodities are covered by the ITA (denoted by ITA = 1); from Table 3, these industries are computers, peripherals and 
semiconductors. The second regression is run over those industries where $50-99 \%$ of the import value covered by the ITA $(0.5 \leq$ ITA $<1)$, and the third regression is run over those industries where $1-49 \%$ of the import value is covered by the ITA $(0<$ ITA $<0.5)$. The fourth regression is run over a control group of industries that include no ITA commodities. ${ }^{17}$

Looking first at the regression for ITA $=1$, which includes computers, peripherals and semiconductors, the indicator variables for the ITA tariff cuts (July 1997, January 1998 and January 1999) are all negative, indicating a drop in prices that is not accounted for by the tariff variable. The cumulative drop due to the indicator variables exceeds $20 \%$. The tariff variable itself has a "pass-through" coefficient of 22.6, which is extremely larger than normally found and indicates that the tariff declines have a highly magnified effect on lowering the import prices. Admittedly, the tariffs themselves are very low in these industries (see Table 3), so even with the very large pass-though coefficient, the impact of the tariff cuts on import prices is still modest. The exchange rate coefficients reported are the sum of coefficients on the current and six lagged values. These estimates show that a $10 \%$ permanent appreciation of foreign currencies results in a 3.5\% increase in U.S. import prices.

Turning to the next regression (2), this is run over industries with $50-99 \%$ of the import value covered by ITA products, or $0.5 \leq$ ITA $<1$. This regression indicates a tariff pass-through coefficient of 2.5, so again, there is a magnified impact of the ITA tariff cuts on the import prices. Our explanation for these results is that the ITA was a multilateral tariff reduction, with U.S. tariff cuts matched by those abroad, so with imports being processed in multiple countries their prices can easily fall by more than the drop in U.S. tariffs. The third regression includes industries where $1-49 \%$ of the import value is covered by the ITA, and it now has a tariff pass-

\footnotetext{
${ }^{17}$ The control group of industries used in the final regressions include capital goods (Enduse 2), automobiles and parts (Enduse 3), and consumer goods (Enduse 4).
} 
through of unity. In both of these regressions, the ITA indicator variables are much smaller than found with ITA $=1$, so that most of the impact of the ITA is through the tariff cuts.

The final regressions in Table 4 are for a control group of capital and consumer goods industries that do not include any commodities affected by the ITA tariff cuts. For these industries, we find a tariff coefficient of 0.86 for OLS, but this is insignificantly different from unity. ${ }^{18}$ The fact that this control group provide the "small country" result for tariff pass-through gives us confidence that the magnified tariff effects found for industries with ITA $\geq 0.5$ shows that those tariff cuts really do reflect the multilateral nature of the ITA.

In addition to OLS, we have also estimated the regressions with "pooled mean group" (PMG), which accounts for unit-roots in the time series and is maximum likelihood for cointegrated panels. ${ }^{19}$ In this case, we combine the industries with ITA > 0 in regression (5), while the control group with ITA $=0$ is shown in regression (6). The PMG estimate of the tariff coefficient for the ITA $>0$ sample is 4.9 , which is still significantly greater than unity and indicated a magnified impact of the tariff cuts. In contrast, the control group has a tariff coefficient of exactly unity, which is the "small country" result.

We have also investigated the impact of the ITA on import variety, using data from 1989 to 2006 on all 5-digit Enduse industries. Rather than attempt to structurally model the growth in import variety, we perform a simple difference-in-difference test to evaluate the impact of the ITA. We use the inverse of (17) to measure import variety on an annual basis, and specify the difference-in-difference test as:

\footnotetext{
${ }^{18}$ We have also estimated the price regression for subsets of the control group, which include capital goods (Enduse 2), automobiles and parts (Enduse 3), and consumer goods (Enduse 4). In each of these three categories, the tariff coefficient is insignificantly different from unity. The only Enduse category besides the ITA industries that consistently show a tariff coefficient greater than unity is Enduse 12500, which is chemicals.

${ }^{19}$ The PMG estimator, coded by Blackburne and Frank (2007), is available in STATA as the xtpmg command. The time-series properties of the data is investigated in Bergin and Feenstra (2009).
} 


$$
\begin{array}{r}
-\ln \Lambda_{\mathrm{mi}}^{\mathrm{t}}=1(\mathrm{ITA}=1) \cdot 1(\text { Year } \geq 1997)+1(0.5 \leq \mathrm{ITA}<1) \cdot 1(\text { Year } \geq 1997) \\
+1(0<\mathrm{ITA}<0.5) \cdot 1(\text { Year } \geq 1997)+\text { Industry and year fixed effects, }
\end{array}
$$

where $1(\cdot)$ are indicator variables returning a value of unity when the statement $(\cdot)$ is true, and zero otherwise. In addition to the specification (20), we also experiment with a single indicator variable for industries with any percentage of commodities impacted by the ITA (i.e. ITA > 0), which is still interacted with the dates after the ITA was in effect (i.e. Year $\geq 1997$ ). In the first panel of Table 5, we use all Enduse industries, including agriculture, raw materials, capital goods, autos, and consumer goods. In the second panel we drop agriculture and raw materials, focusing on Enduse 2 - 4 (capital, autos and consumer goods).

The first regression reported in Table 5 uses OLS, along with all Enduse industries. Two out of three interaction terms in (20) between the ITA industries and the time of the ITA agreements are significant in that case. In the second regression we weight the regressions by the value of imports, and in that case all three interaction terms are significant, with an increase in import variety of $4.2 \%$ for the industries covered entirely by the agreement, i.e. computers, peripherals and semiconductors. If we omit agricultural goods and raw materials, in either the OLS or WLS regressions in the right panel of Table 5, then we find nearly a 6\% increase in variety for those ITA industries covered fully by the agreements, with smaller increases for those industries partially covered by the agreement. Furthermore, there is an average $4.5 \%$ increase in variety over all industries impacted by the ITA (in the final regression). ${ }^{20}$ We turn now to the question of how the drop in prices and increase in import variety due to the ITA has influenced the measurement of productivity growth in the United States.

\footnotetext{
${ }^{20}$ It is worth emphasizing that because we are incorporating the elasticity of substitution $1 /\left(\sigma_{\mathrm{h}}-1\right)$ into the definition of variety in (17), the actual increase in variety is larger than indicated by these regression coefficients, e.g. twice as high for $\sigma_{\mathrm{h}}=3$, or three times as high for $\sigma_{\mathrm{h}}=4$.
} 


\section{Terms of Trade and Productivity Growth for the United States}

To investigate the sensitivity of estimates of productivity growth to unmeasured gains in terms of trade, we calculate alternative versions of the deflators of exports and imports on which the estimates of productivity depend. The Major Sector Productivity and Costs Program in BLS's Office of Productivity and Technology uses measures of the output of private business and nonfarm private business from BEA. ${ }^{21}$ Therefore the relevant deflators are the ones calculated by BEA using weights from the National Income and Product Accounts (NIPAs) and price indexes for detailed items from BLS. In the case of exports and imports, the detailed price indexes are generally the 5-digit Enduse level indexes from the International Price Program.

We first replicate BLS’s Laspeyres price indexes for 5-digit Enduse exports and imports to obtain a baseline for our comparisons. To obtain the building blocks for our corrected deflators, we construct parallel export and import price indexes using a Törnqvist index formula, and for imports we calculate additional sets of Törnqvist indexes that include tariffs and variety effects, as described in section 4 . We then aggregate the various versions of the 5-digit Enduse indexes using the Fisher index formula price with weights from the NIPAs to obtain deflators for merchandise exports and for non-petroleum merchandise imports.

Table 6 reports the results for our Törnqvist export price indexes and the three kinds of import price indexes: the Törnqvist, the tariff-inclusive Törnqvist, and the tariff-inclusive Törnqvist adjusted for variety effects. Unsurprisingly, replacing the Laspeyres index with the Törnqvist index has a smaller effect when a Fisher index is used for higher-level aggregation than it did when a Laspeyres index was used at all stages of aggregation (as shown in Figure 1). Using the Törnqvist formula to calculate the detailed indexes, and incorporating tariffs and

\footnotetext{
${ }^{21}$ BLS previously made a minor adjustment to BEA's output measure (Fraumeni et al., p. 379), but this is no longer necessary.
} 
import variety, reduces the growth rate of our aggregate Fisher export index by $0.57 \%$ per year, with one-half of this effect coming from ICT goods. The Törnqvist formula reduces the growth rate of the aggregate import price index by a larger amount, $1.58 \%$ per year, with ICT goods accounting for one-third of that effect. From 1996 to 2006, the increase in the growth rate of the terms of trade index is then the difference between these two figures, or $1.05 \%$ per year.

Because ICT goods sometimes contribute more to falling export prices than import prices, their contribution to the overall reduction in the terms of trade is modest - only $18 \%$ of the total increase. On the other hand, the contribution of improvements in import variety towards improving the terms of trade is substantial : without that effect, the terms of trade would be rising by $0.3 \%$ per year on average - rather than $1.05 \%$ - due to using the Törnqvist formula at the lower level (and only $0.2 \%$ per year on average if falling tariff are also excluded). ${ }^{22}$ This supports the hypothesis that entry of lower priced varieties from new sources of supply caused a substantial drop in import prices that was missed by the standard methods used to construct official indexes.

To summarize, the combined effect of the three index corrections on the growth rate of the terms of trade averages 1.05 percent per year in 1996-20069 (though it is virtually zero in 1995). This unmeasured gains in the Fisher terms of trade index is large enough to affect measures of aggregate output significantly starting in 1996. To investigate effects on measures of aggregate output, we use our Laspeyres export and import indexes to calculate baseline price indexes for GDP, for total value added (i.e. the revenue function), and for the value added of private business. We then compared the price indexes for these three aggregates to ones calculated using the Törnqvist export index and the tariff-inclusive Törnqvist import index

\footnotetext{
${ }^{22}$ It is unusual to incorporate falling tariffs into a calculation of the terms of trade, but natural to do so in our context because we have shown in (6) that the tariff-inclusive prices $\tilde{\mathrm{P}}^{\mathrm{t}}$ should be used to deflate $\mathrm{R}^{\mathrm{t}}$.
} 
adjusted for variety effects. The price indexes for value added includes tariffs in the weight for imports, as is logical when tariffs are included in the prices and weights used to calculate the import price index, like in equation (7).

We calculated the indexes for all three aggregate output concepts using both a Törnqvist formula and a Fisher formula to aggregate domestic final consumption, goods exports, services exports, non-petroleum goods imports, services imports and petroleum imports. As expected, the Törnqvist and Fisher results were identical for practical purposes.

From 1996 through 2006, the effect of our corrected export and import indexes on the growth rate of the price index for GDP ranged from 0.07 to 0.25 percent per year (see Table 7 , section I), and averaged $0.13 \%$ per year. The effect on the Fisher price index for total value added (for which no official index exists) averages $0.14 \%$ per year during that period (Table 7 , section II). That is, this deflator for total value added grows by $0.14 \%$ more per year that the deflator based on the official import and export prices indexes: the slower growth of our Törnqvist import indexes, adjusted for tariffs and variety effects, leads to more rapid growth of the deflator for value-added, and therefore a slower real growth of value added. That slower growth of value added translates into slower productivity growth of the same magnitude. Taking into account the difference between the growth of nominal GDP and value added, which depends on the change in total tariff revenue and appears as the first two terms on the right of equation (10), has only minimal impact.

If we ignore the government sector and focus on private business, then the effect on the price index for gross value added of private business ranges from 0.10 to 0.34 percent per year, with an average of $0.19 \%$ over 1996-2006 (Table 7, section III). Again, the slower growth of our Törnqvist import indexes, adjusted for tariffs and variety effects, leads to more rapid growth of 
the deflator for private business value added, and therefore a slower real growth of value added. The further adjustment for changes in total tariff revenue has only minimal impact. The official quantity index for the output of private business (rebased to 1994=100) in 2006 is 154.0, compared with our corrected index of 151.1, with all of the 2.9 percentage point gap coming from the ten years of 1996 to 2006. On a cumulative basis, unmeasured gains in terms of trade therefore can account for 0.18 percent per year to the official measure of productivity growth over the period 1996 through 2006.

To gauge the importance of this terms-of-trade mismeasurement, recall that reported growth in U.S. nonfarm labor productivity has accelerated from 1.40 percent during 1973-1995 to 2.55 percent during 1996-2007-i.e., by about 1.15 percent per year. Our results suggest that about $16 \%$ of this reported economy-wide acceleration in labor productivity should properly be accounted for by terms-of-trade improvements. Furthermore, current BLS statistics report that U.S. nonfarm TFP growth accelerated from $0.53 \%$ per year over $1987-1995$ to $1.41 \%$ per year over 1996-2006. Our results suggest that about $20 \%$ - or one-fifth - of this reported economywide acceleration in TFP should properly by accounted for by terms-of-trade improvements. The U.S. economy in the past decade clearly did enjoy faster productivity growth. But the magnitude of this acceleration has been overstated, with a sizable share of the gains actually being accounted for by the benefits of international trade.

Two caveats concerning the results in Table 7 are worth mentioning. First, we have included imported finished investment goods in our corrected import price indexes even though their deflators have no effect on the measurement of real GDP. These goods are deflated by import price indexes in calculating the investment component of GDP, so the effects of any bias in their price indexes cancel out when the imports and investment components of GDP are 
combined. Nevertheless, these price indexes $d o$ affect the measurement of TFP because estimates of capital services inputs are based on accumulated real net investment. Thus, for purposes of estimating effects on productivity measurement, we are correct to include imported investment goods in our analysis. ${ }^{23}$ In any event, these goods account for only a small fraction (probably well under a tenth) of the total effect on measured real GDP growth in 1996-1999.

Second, we simulated the BLS indexes for semiconductors in all years in Tables 6 and 7, but until 1997 BEA used the hedonic indexes of Grimm (1998) rather than indexes from BLS for semiconductors. Even though the hedonic indexes fell faster than the matched model indexes of BLS, the change to the BLS indexes had little effect on estimates of real GDP because U.S. trade in semiconductors was approximately balanced in the late 1990s, and the Grimm indexes and BLS indexes both tended to imply similar small gains in terms of trade for this item. Excluding semiconductors from our analysis before 1998 would have changed the overall estimate of the unmeasured terms of trade gains in the next-to-last row of Table 6 by +0.05 percentage points in 1995 and by -0.15 percentage points in 1996 and 1997. On average over 1995-2006, the contribution of semiconductors to our estimate of unmeasured terms of trade gains is virtually zero, but in one year (2000) excluding semiconductors raises our estimate by 0.4 percentage points.

\section{Conclusions}

At first glance, the roles of trade prices and trade barriers in aggregate productivity measurement might seem small. But as we have shown in this paper, for many reasons they can be very important. Unmeasured gains in the terms of trade cause real output growth and

\footnotetext{
${ }^{23}$ The way capital services inputs are calculated slightly attenuates the effect on estimated TFP compared with the effect that would occur if the deflators for imported investment goods affected the output side of the calculation.
} 
productivity growth to be overstated, and declines in tariffs can also be expected to raise productivity. Building on the GDP function approach of Diewert and Morrison, in this paper we have developed new methods for measuring these effects. We have then applied this framework to the important case of the post-1995 U.S. productivity acceleration.

Our main result is that approximately $20 \%$ of the apparent speed-up in U.S. productivity growth as officially reported was actually gains in the terms of trade and tariff reductionsespecially for the IT products that have been the focus of much research on U.S. productivity. In generating this result, we analyzed three important sources of mis-measurement in the U.S. terms of trade: (i) the import and export prices indexes published by the BLS are Laspeyres indexes, rather than a superlative formula; (ii) in the calculation of GDP, imports exclude duties, and the BLS import indexes—which the Bureau of Economic Analysis (BEA) uses to deflate imports— also measure import prices free of tariffs; and (iii) the BLS import price index does not account for increases in the variety of imports coming from new supplying countries. The average growth rates of our corrected price indexes for U.S. imports are 1.5\% per year lower than growth rate of the index calculated using official methods, a key input to reaching our main result.

Although our focus in this paper was on the particular case of the post-1995 U.S. productivity acceleration, the issues we identified and methods we developed generalize along at least three important and related dimensions.

First, our analysis could be extended to address other U.S. price series that cover nontraded parts of the economy and thus help create aggregate productivity statistics. For example, deflators for domestic absorption are beyond the scope of the research in this paper but could be examined for possible biases due to expanded product variety. 
Second, our analysis could be applied to better understand U.S. economic performance in earlier periods. From 1948 to 1973, for example, officially measured non-farm U.S. labor productivity grew at an annual average of $2.79 \%$ - a rapid rate that often leads this period to be a "golden generation" in U.S. economic history. But this was also a period of fast growth in U.S. trade with rapidly growing countries like Japan, and also of substantial U.S. trade liberalization thanks, e.g., to the Kennedy Round of the General Agreement on Tariffs and Trade. These broad facts suggest potential value in re-examining this period's productivity statistics.

And third, our analysis could be extended to the growth experience of other countries. Countries such as China and India appear to have recently delivered productivity gains among the fastest the world has ever seen (the recent crisis notwithstanding). At the same time, many of these countries have rapidly integrated into the world economy with dramatic declines in trade barriers and surging trade flows. As with the post-World War II U.S. generation, so, too, the growth experiences of these other countries might look different by our analysis. 


\section{Appendix: International Price Data}

To calculate all the price indexes, we use two datasets provided by the International Price Program (IPP) program. The first dataset spans September 1993 to December 1996 and was used extensively in Alterman, Diewert and Feenstra (1999). That dataset contains long-term price relatives (that is, $\mathrm{p}_{\mathrm{i}}^{\mathrm{t}} / \mathrm{p}_{\mathrm{i}}^{0}$ ) at the "classification group" level, which is similar to the 10-digit Harmonized System (HS) level. The classification groups have been carefully concorded to the HS system, so that the base-period weights (for 1990) used by the IPP program can be replaced by current annual import and export expenditures in order to calculate the Törnqvist indexes. That is, current annual weights are used in the Törnqvist index when aggregating from the classification group level to the Enduse industries.

A second dataset spans January 1997 to December 2006. The classification groups used in that dataset differ somewhat from those used in the earlier period, so we have developed an (incomplete) concordance between them. The price data available for this latter period are actually more detailed than the classification group level, and go down to the "item" level at which individual companies provide price quotes. So for this latter period, we first need to aggregate from the item level to the classification group level, and then aggregate from the classification groups to the Enduse industries. The lower-level aggregation (from the item level to the classification group) can be done using the base-period (1995) weights and the Laspeyres formula, which follows the BLS procedure. Alternatively, the lower-level aggregation can be done using the base-period weights and a geometric formula. After constructing geometric indexes at the lower-level, we proceed by applying the Törnqvist index to aggregate the indexes for the classification groups to the Enduse industries. 


\section{References}

Alterman, William, W. Erwin Diewert and Robert C. Feenstra. 1999. International Trade Price Indexes and Seasonal Commodities. U.S. Department of Labor, Bureau of Labor Statistics, Washington, D.C.

Baily, Martin Neil, and Robert Z. Lawrence. 2001. “Do We Have a New E-Conomy?” American Economic Review, 91 (2), pp. 308-312.

Bergin, Paul R. and Robert C. Feenstra, 2009, "Pass-through of Exchange Rates and Competition Between Fixers and Floaters,” Journal of Money, Credit and Banking, February, 41(s1), 35-70.

Blackburne, Edward F. and Mark W. Frank., 2007, "Estimation of Nonstationary Heterogeneous Panels,” The STATA Journal, 7(2), 197-208.

Bosworth, Barry P., and Jack E. Triplett. 2000. "What’s New About the New Economy? IT, Economic Growth and Productivity.” Brookings Institution manuscript, December.

Broda, Christian and David E. Weinstein, 2006, "Globalization and the Gains from Variety," Quarterly Journal of Economics, May, 121(2), 541-585.

Bureau of the Census, 1992-2000, U.S. Exports and Imports of Merchandise on CD-ROM [machine-readable data file], Washington, D.C.

Diewert, W. Erwin, 1976, “Exact and Superlative Index Numbers,” Journal of Econometrics, 4, 115-146.

Diewert, W. Erwin. 2006. Comment on "Aggregation Issues in Integrating and Accelerating BEA's Accounts: Improved Methods for Calculating GDP by Industry", in A New Architecture for the U.S. National Accounts, D.W. Jorgenson, J.S. Landefeld and W.D. Nordhaus, eds., Univ. of Chicago Press for the Conference on Research in Income and Wealth (CRIW).

Diewert, W. Erwin, 2008, “Changes in the Terms of Trade and Canada's Productivity Performance,” University of British Columbia.

Diewert, W. Erwin and Catherine J. Morrison. 1986. "Adjusting Outputs and Productivity Indexes for Changes in the Terms of Trade.” Economic Journal, 96, pp. 659-679.

Feenstra, Robert C., 1994, "New Product Varieties and the Measurement of International Prices,” American Economic Review, 84(1), March, 157-177.

Fraumeni, Barbara M., Michael J. Harper, Susan G. Powers, and Robert E. Yuskavage. 2006.

"An Integrated BEA/BLS Production Account: A First Step and Theoretical Considerations." In A New Architecture for the US National Accounts, Dale W. Jorgenson, J. Steven Landefeld and William D. Nordhaus, eds. Studies in Income and Wealth Vol. 66, Chicago: Univ. of Chicago Press. 
Gordon, Robert J. 2003. "High-Tech Innovation and Productivity Growth: Does Supply Create Its Own Demand.” National Bureau of Economic Research Working Paper \#9437.

Gordon, Robert J. 2000. "Does the 'New Economy' Measure up to the Great Inventions of the Past?” Journal of Economic Perspectives, Vol. 14. No. 4, Fall, pp. 49-74.

Gullickson, William and Michael J. Harper. 1999. "Possible Measurement Bias in Aggregate Productivity Growth.” Monthly Labor Review 122, no. 2, February, 47-67.

Houseman, Susan, 2007, “Outsourcing, Offshoring, and Productivity Measurement in Unisted States Manufacturing,” International Labour Review, 146(1-2), 61-80.

Hummels, David and Peter Klenow, 2005, “The Variety and Quality of a Nation’s Trade,” American Economic Review, 95(3), June, 704-723.

Jorgenson, Dale W., 2001, “Information Technology and the U.S. Economy.” American Economic Review, 91(1), pp. 1-32.

Jorgenson, Dale W. and Zvi Griliches, 1972, "Issues in Growth Accounting: A Reply to Edward F. Denison”, Survey of Current Business 52:5, Part II, 65-94.

Jorgenson, Dale W. and Kevin J. Stiroh. 2000a. “Information Technology and Growth.” American Economic Review, 89(2), pp. 109-115.

Jorgenson, Dale W. and Kevin J. Stiroh. 2000b. "Raising the Speed Limit: U.S. Economic Growth in the Information Age.” Brookings Papers on Economic Activity, 1, pp. 125-211.

Kehoe, Timothy J., and Kim J. Ruhl. 2008. "Are Shocks to the Terms of Trade Shocks to Productivity?” Review of Economic Dynamics, 11(4), 804-819.

Kohli, Ulrich R., 1990, “Growth Accounting in an Open Economy.” Journal of Economic and Social Measurement 16, 125-36.

Kohli, Ulrich R., 2004, "Real GDP, Real Domestic Income, and Terms-of-Trade Changes.” Journal of International Economics, 62(1), pp 83-106.

Kohli, Ulrich R., 2005, “Labour Productivity vs. Total Factor Productivity.” IFC Bulletin 20 (April), Irving Fisher Committee on Central Bank Statistics, International Statistical Institute.

Kohli, Ulrich R, 2006, “Terms of Trade, Real GDP, and Real Value-Added in an Open Economy: Reassessing Hong Kong's Growth Performance.” Hong Kong Institute for Monetary Research Working Paper No. 5/2006. 
Mann, Catherine L, 2003, "Globalization of IT Services and White Collar Jobs: The Next Wave of Productivity Growth.” Washington, D.C.: Institute for International Economics Policy Brief \#PB03-11.

Nordhaus, William D. 2005. "The Sources of the Productivity Rebound and the Manufacturing Employment Puzzle.” National Bureau of Economic Research Working Paper \#11,354.

Nordhaus, William D. 2001. "Productivity Growth and the New Economy.” Brookings Papers on Economic Activity, 2001:2, pp. 211-265.

Oliner, Stephen D. and Daniel E. Sichel. 2002. "Information Technology and Productivity: Where Are We Now and Where Are We Going?” Federal Reserve Board manuscript dated May 10, to be published in Atlanta Federal Reserve Bank Review.

Oliner, Stephen D. and Daniel E. Sichel, 2000, "The Resurgence of Growth in the Late 1990s: Is Information Technology the Story?” Journal of Economic Perspectives, 14(4), pp. 3-22.

Sato, Kazuo, 1976, “The Ideal Log-change Index Number,” Review of Economics and Statistics 58, May, 223-228.

Vartia, Y.O., 1976, “Ideal Log-change Index Numbers,” Scandinavian Journal of Statistics 3, 121-126.

Yi, Kei-Mu. 2002. “Can Vertical Specialization Explain the Growth of World Trade?” Journal of Political Economy. 
Table 1: International Trade in ICT Industries (\$million)

\begin{tabular}{llccc}
\hline \hline Industry & & 1992 & 1996 & 2000 \\
\hline Computers (Enduse 21300) & Exports & 8,277 & 10,422 & 10,263 \\
& Imports & 5,042 & 6,927 & 14,284 \\
& Trade Balance & 3,235 & 3,495 & $-4,022$ \\
Computer accessories & Exports & 16,730 & 27,550 & 34,686 \\
(Enduse 21301) & Imports & 26,659 & 54,590 & 75,514 \\
& Trade Balance & $-9,929$ & $-27,040$ & $-40,828$ \\
Semiconductors & Exports & 11,527 & 24,135 & 45,118 \\
(Enduse 21320) & Imports & 15,477 & 36,713 & 48,341 \\
& Trade Balance & $-3,950$ & $-12,579$ & $-3,223$ \\
Telecommunications & Exports & 10,520 & 19,137 & 28,987 \\
Equipment (Enduse 214) & Imports & 10,773 & 14,505 & 38,203 \\
& Trade Balance & -253 & 4,633 & $-9,216$ \\
Total (Enduse 213+214) & Exports & 47,054 & 81,244 & 119,054 \\
& Imports & 57,952 & 112,735 & 176,343 \\
& Trade Balance & $-10,898$ & $-31,491$ & $-57,289$ \\
Share in Overall Trade (percent) & Exports & 10.7 & 13.3 & 15.4 \\
& Imports & 12.0 & 15.4 & 16.0 \\
& Trade Balance & 24.1 & 26.6 & 17.2 \\
\hline
\end{tabular}

Notes: Trade exports and imports are in millions of current dollars, and trade balance equals exports minus imports. Source: Trade data for Enduse industries comes from Bureau of the Census, 1992-2000. The export, import and trade balance shares are computed by dividing trade in Enduse 213+214 by total U.S. exports, non-petroleum imports, and the non-petroleum trade deficit, from Economic Report of the President, 2004, Table B-104.

Table 2: Trade Intensity of IT Commodities in the 1997 Benchmark I-O Tables (percent)

\begin{tabular}{lccc}
\hline \hline Commodity & $\begin{array}{l}\text { \% of Commodity } \\
\text { Output Exported }\end{array}$ & $\begin{array}{l}\text { \% of Commodity } \\
\text { Output Imported }\end{array}$ & $\begin{array}{l}\text { Trade } \\
\text { Balance }\end{array}$ \\
\hline $\begin{array}{l}\text { Computer \& peripheral } \\
\text { equipment }\end{array}$ & 19.2 & 37.8 & -18.7 \\
$\begin{array}{l}\text { Semiconductors \& } \\
\text { Electronic components }\end{array}$ & 36.1 & 36.6 & -0.5 \\
Manufacturing Products & 13.8 & 20.5 & -6.7 \\
\hline Source: Calo
\end{tabular}

Source: Calculated from the "Use of Commodities" tables in the U.S. BEA's Input-Output Accounts. 
Table 3: Features of ITA Industries

\begin{tabular}{|c|c|c|c|c|}
\hline Industry & $\begin{array}{c}\text { \% Imports } \\
\text { covered by } \\
\text { ITA }\end{array}$ & $\begin{array}{c}1997 \\
\text { Tariff } \\
\text { (percent) }\end{array}$ & $\begin{array}{c}2000 \\
\text { Tariff } \\
\text { (percent) }\end{array}$ & $\begin{array}{l}\text { Variety } \\
\text { Growth } \\
\text { 1996-06 } \\
\text { (percent) }\end{array}$ \\
\hline Computers (Enduse 21300) & 100 & 1.4 & 0.0 & 8.5 \\
\hline Computer accessories (21301) & 100 & 0.3 & 0.0 & 7.7 \\
\hline Semiconductors (21320) & 100 & 0.0 & 0.0 & 23.0 \\
\hline Average variety growth $(I T A=1)$ & & & & 13.0 \\
\hline Blank tapes (16110) & 92 & 1.5 & 0.0 & -0.8 \\
\hline Telecomm equipment (21400) & 79 & 2.6 & 0.3 & 32.8 \\
\hline Lab Instruments (21600) & 63 & 3.7 & 2.3 & 14.2 \\
\hline Records, tapes \& disks (41220) & 61 & 1.0 & 0.2 & 12.9 \\
\hline Ave. variety growth $(0.5 \leq I T A<1)$ & & & & 14.8 \\
\hline Electrical apparatus (20005) & 48 & 2.3 & 1.1 & 8.8 \\
\hline Business machines (21500) & 39 & 2.0 & 0.7 & -1.5 \\
\hline Generators \& access (20000) & 38 & 1.6 & 1.5 & 4.6 \\
\hline $\begin{array}{l}\text { Measuring, testing, control } \\
\text { instruments (21160) }\end{array}$ & 30 & 1.8 & 0.9 & 4.5 \\
\hline Marine engines and parts (22220) ${ }^{\mathrm{a}}$ & 23 & 1.6 & 0.3 & 28.0 \\
\hline Wood, glass, plastic (21140) & 21 & 2.2 & 1.9 & 37.7 \\
\hline Photo, service industry (21190) & 21 & 2.1 & 1.4 & 19.9 \\
\hline Metalworking machine tools (21120) & 19 & 3.3 & 2.9 & 0.9 \\
\hline Materials handling equip (21170) & 16 & 0.4 & 0.1 & 5.2 \\
\hline Industrial supplies, other (16120) & 13 & 2.1 & 1.7 & 4.3 \\
\hline Industrial machines, other (21180) & 11 & 2.2 & 1.6 & 4.6 \\
\hline Average variety growth $(0<I T A<0.5)$ & & & & 9.8 \\
\hline Average variety growth $(I T A=0)$ & & & & 8.0 \\
\hline
\end{tabular}

Notes:

a. Within marine engines and parts (22220), the product receiving ITA tariff cuts was radar equipment. Omitted from this table are industries where less than $10 \%$ of imports are covered by the ITA 
Table 4: Pass-through Regressions, Dependent Variable - Import Price

\begin{tabular}{|c|c|c|c|c|c|c|}
\hline & (1) & $(2)$ & (3) & (4) & (5) & (6) \\
\hline & \multicolumn{4}{|c|}{ Fixed-Effects OLS } & \multicolumn{2}{|c|}{ PMG } \\
\hline & \multicolumn{4}{|c|}{ By portion of products covered by the ITA: } & \multirow[b]{2}{*}{ ITA $>0$} & \multirow[b]{2}{*}{$\mathrm{ITA}=0$} \\
\hline & $\mathrm{ITA}=1$ & $0.5 \leq \mathrm{ITA}<1$ & $0<$ ITA $<.5$ & $\mathrm{ITA}=0$ & & \\
\hline \multirow[t]{2}{*}{ ITA1 } & -0.036 & $-0.017^{*}$ & $-0.033^{\star \star}$ & -0.005 & -0.023 & -0.005 \\
\hline & $(0.027)$ & $(0.007)$ & $(0.005)$ & $(0.004)$ & $(0.016)$ & $(0.003)$ \\
\hline \multirow[t]{2}{*}{ ITA2 } & -0.037 & -0.002 & -0.011 & 0.002 & -0.013 & $-0.013^{* *}$ \\
\hline & $(0.029)$ & $(0.007)$ & $(0.006)$ & $(0.004)$ & $(0.019)$ & $(0.003)$ \\
\hline \multirow[t]{2}{*}{ ITA3 } & $-0.158^{\star \star}$ & 0.003 & $-0.030 * *$ & $-0.015^{\star \star}$ & -0.005 & 0.006 \\
\hline & $(0.023)$ & $(0.005)$ & $(0.004)$ & (0.003) & $(0.014)$ & $(0.004)$ \\
\hline \multirow[t]{2}{*}{ Tariff } & $22.602^{\star \star}$ & $2.503^{\star *}$ & $1.022^{\star \star}$ & $0.859 * *$ & $4.88^{\star \star}$ & $1.01^{\star \star}$ \\
\hline & (1.192) & $(0.284)$ & $(0.349)$ & $(0.096)$ & $(0.176)$ & $(0.281)$ \\
\hline \multirow{2}{*}{$\begin{array}{l}\text { Exchange Rate } \\
\text { (6 lags) }\end{array}$} & $0.353^{* *}$ & $0.083^{* *}$ & $0.101^{* *}$ & $0.344^{\star *}$ & $1.09 * \star$ & $0.541^{\star \star}$ \\
\hline & $(0.104)$ & $(0.027)$ & (0.019) & $(0.013)$ & $(0.173)$ & $(0.039)$ \\
\hline \multirow{2}{*}{$\begin{array}{l}\text { Exch. Rate } \\
\text { x Peg Share }\end{array}$} & $-0.610^{* *}$ & $-0.359 * *$ & $-0.662^{\star \star}$ & $-0.516^{\star *}$ & $-2.01^{\star \star}$ & $-0.923^{\star *}$ \\
\hline & $(0.237)$ & $(0.132)$ & $(0.075)$ & $(0.036)$ & $(0.372)$ & $(0.067)$ \\
\hline \multirow[t]{2}{*}{ Peg Share } & $2.565^{\star}$ & $1.506^{* *}$ & $2.965^{\star \star}$ & $2.432^{\star \star}$ & $9.56 * \star$ & $4.09 * \star$ \\
\hline & (1.153) & $(0.639)$ & $(0.358)$ & $(0.174)$ & $(0.180)$ & $(0.309)$ \\
\hline \multirow[t]{2}{*}{ Export Price } & $0.668^{\star \star}$ & $1.007^{* *}$ & $1.072^{* *}$ & $0.241^{* *}$ & $1.27^{\star \star}$ & $0.155^{\star \star}$ \\
\hline & $(0.047)$ & $(0.027)$ & $(0.023)$ & $(0.016)$ & $(0.065)$ & $(0.038)$ \\
\hline \multirow{2}{*}{$\begin{array}{c}\text { Observations } \\
\mathbf{R}^{2}\end{array}$} & 439 & 474 & 1659 & 2694 & 2535 & 2634 \\
\hline & 0.98 & 0.97 & 0.92 & 0.80 & & \\
\hline
\end{tabular}

Notes: * significant at $5 \%,{ }^{* *}$ significant at $1 \%$; Standard errors are in parentheses.

Regressions are run over 5-digit Enduse industries, with monthly data from September 1993 - December 2006. Regressions with ITA $=1$ are run over those industries where $100 \%$ of the imports are covered by the ITA; regressions with $0.5 \leq$ ITA $<1$ are run over those industries where $50-99 \%$ of the import value covered by the ITA; and regressions with $0<$ ITA $<0.5$ are run over those industries where $1-49 \%$ of the import value is covered by the ITA. The final regressions with ITA $=0$ are run over a control group of industries (Enduse 2,3,4) that do not include any ITA commodities as imports. Regressions are estimated with either OLS (including fixed effects for 5-digit Enduse industries) or PMG (pooled mean group), which corrects for unit-roots in the time series. The OLS regressions include 6 lags of the exchange rate, whereas the PMG routine chooses its own lag length for the exchange rate and other dependent variables. 


\section{Table 5: Difference-in-Difference Test,} Dependent Variable - Import Variety

\begin{tabular}{|c|c|c|c|c|c|c|c|c|}
\hline \multicolumn{9}{|c|}{ Enduse categories included in analysis: } \\
\hline & \multicolumn{4}{|c|}{$\begin{array}{c}\text { All Enduse industries } \\
\text { (agriculture, raw materials capital, } \\
\text { autos, and consumer goods) }\end{array}$} & \multicolumn{4}{|c|}{$\begin{array}{c}\text { Enduse 2-4 } \\
\text { (capital, autos, consumer goods) }\end{array}$} \\
\hline & OLS & WLS & OLS & WLS & OLS & WLS & OLS & WLS \\
\hline (ITA=1).(Year $\geq 1997)$ & $\begin{array}{l}0.039^{\star} \\
(0.024)\end{array}$ & $\begin{array}{l}0.042^{\star \star} \\
(0.010)\end{array}$ & & & $\begin{array}{l}0.059^{\star \star} \\
(0.019)\end{array}$ & $\begin{array}{l}0.058^{\star \star} \\
(0.008)\end{array}$ & & \\
\hline$(0.5 \leq 1 T A<1) \cdot(Y e a r \geq 1997)$ & $\begin{array}{l}-0.020 \\
(0.021)\end{array}$ & $\begin{array}{l}0.035^{*} \\
(0.018)\end{array}$ & & & $\begin{array}{c}0.012 \\
(0.019)\end{array}$ & $\begin{array}{l}0.062^{\star *} \\
(0.015)\end{array}$ & & \\
\hline$(0<I T A<0.5) \cdot(Y e a r \geq 1997)$ & $\begin{array}{l}0.025^{\star \star} \\
(0.011)\end{array}$ & $\begin{array}{l}0.014^{*} \\
(0.008)\end{array}$ & & & $\begin{array}{l}0.048^{\star \star} \\
(0.009)\end{array}$ & $\begin{array}{l}0.032^{\star *} \\
(0.007)\end{array}$ & & \\
\hline$($ ITA $>0) \cdot($ Year $\geq 1997)$ & & & $\begin{array}{c}0.019^{* *} \\
(0.009)\end{array}$ & $\begin{array}{c}0.027^{* *} \\
(0.006)\end{array}$ & & & $\begin{array}{l}0.044^{\star \star} \\
(0.008)\end{array}$ & $\begin{array}{l}0.045^{\star \star} \\
(0.006)\end{array}$ \\
\hline $\begin{array}{l}\text { Observations } \\
\mathrm{R}^{2}\end{array}$ & $\begin{array}{c}2,536 \\
0.41\end{array}$ & $\begin{array}{c}2,536 \\
0.70\end{array}$ & $\begin{array}{c}2,536 \\
0.41\end{array}$ & $\begin{array}{c}2,536 \\
0.70\end{array}$ & $\begin{array}{c}1,331 \\
0.38\end{array}$ & $\begin{array}{c}1,331 \\
0.69\end{array}$ & $\begin{array}{c}1,331 \\
0.38\end{array}$ & $\begin{array}{c}1,331 \\
0.69\end{array}$ \\
\hline
\end{tabular}

Notes: * significant at $10 \%,{ }^{* *}$ significant at 5\%; Standard errors are in parentheses.

Regressions are run over 5-digit Enduse industries, with annual data from 1989 - 2006. All regressions are estimated with OLS and WLS (using the customs value of imports as weights), and include fixed effects for 5-digit Enduse industries and for years. The first set of regressions include all 5-digit Enduse industries, and the second set include only the Enduse industries beginning with 2, 3, or 4. 
Table 6: Effect of Lower-level Index Formula on Aggregate Fisher

Price Indexes for Exports and Imports

(Differences in percent per year)

Ave.

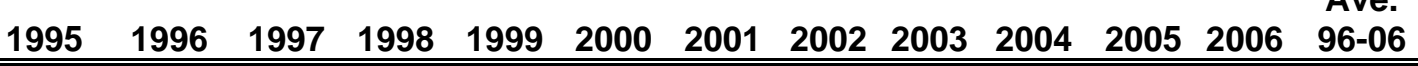

\begin{tabular}{|c|c|c|c|c|c|c|c|c|c|c|c|c|c|}
\hline \multicolumn{14}{|l|}{ I. Export Indexes (1994=100) } \\
\hline \multicolumn{14}{|l|}{ Formula for lower-level aggregates } \\
\hline Laspeyres & 103.1 & 102.6 & 101 & 97.5 & 96 & 97.4 & 96.5 & 95.4 & 96.9 & 100.2 & 103.3 & 106.8 & \\
\hline Törnqvist & 102.4 & 101.8 & 99.7 & 95.6 & 93.6 & 94.1 & 92.8 & 91.1 & 92.2 & 94.7 & 97.1 & 99.6 & \\
\hline Growth rate difference of Törnqvist from Laspeyres & -0.74 & -0.13 & -0.43 & -0.65 & -0.52 & -0.92 & -0.58 & -0.55 & -0.46 & -0.65 & -0.59 & -0.82 & -0.57 \\
\hline Contribution of ICT goods to above difference & -0.09 & -0.18 & -0.24 & -0.4 & -0.28 & -0.63 & -0.39 & -0.18 & -0.1 & -0.21 & -0.15 & -0.24 & -0.27 \\
\hline \multicolumn{14}{|l|}{ II. Import Indexes (1994=100) } \\
\hline \multicolumn{14}{|l|}{ Formula for lower-level aggregates } \\
\hline Laspeyres & 102.6 & 100.7 & 97.7 & 94 & 92.1 & 92.3 & 90.6 & 88.6 & 89.4 & 91.6 & 93.6 & 94.9 & \\
\hline Törnqvist & 102.1 & 99.7 & 95.8 & 90.9 & 88.2 & 87.6 & 85.5 & 83.4 & 83.4 & 84.8 & 86.1 & 86.7 & \\
\hline Törnqvist, tariffs included in prices & 101.8 & 99.3 & 95.3 & 90.3 & 87.5 & 86.9 & 84.8 & 82.5 & 82.5 & 83.9 & 85.1 & 85.7 & \\
\hline Törnqvist, adjusted for tariffs and varieties & 101.8 & 98.8 & 94.2 & 88.4 & 85.4 & 84.4 & 81.6 & 78.9 & 78.7 & 79.5 & 79.9 & 78.9 & \\
\hline \multicolumn{14}{|l|}{ Growth rate difference from Laspeyres } \\
\hline Törnqvist & -0.51 & -0.47 & -0.93 & -1.31 & -0.99 & -0.91 & -0.57 & -0.23 & -0.93 & -0.74 & -0.7 & -0.7 & -0.77 \\
\hline Törnqvist, tariffs included in prices & -0.8 & -0.66 & -0.98 & -1.41 & -1.13 & -1 & -0.55 & -0.41 & -0.96 & -0.81 & -0.71 & -0.69 & -0.85 \\
\hline Törnqvist, adjusted for tariffs and varieties & -0.82 & -1.12 & -1.69 & -2.29 & -1.36 & -1.44 & -1.53 & -0.98 & -1.23 & -1.5 & -1.64 & -2.56 & -1.58 \\
\hline Contribution of ICT goods to above difference & 0.07 & -0.47 & -0.94 & -0.86 & -0.72 & -0.46 & -0.53 & 0 & -0.35 & -0.21 & -0.31 & -0.12 & -0.45 \\
\hline \multicolumn{14}{|l|}{ III. Terms of Trade (1994=100) } \\
\hline \multicolumn{14}{|l|}{ Formula for lower-level aggregates } \\
\hline Laspeyres & 100.4 & 101.9 & 103.4 & 103.8 & 104.2 & 105.5 & 106.5 & 107.7 & 108.4 & 109.4 & 110.4 & 112.6 & \\
\hline Törnqvist & 100.2 & 102 & 104 & 105.2 & 106.1 & 107.4 & 108.5 & 109.3 & 110.6 & 111.7 & 112.8 & 114.9 & \\
\hline Törnqvist, tariffs included in prices & 100.5 & 102.5 & 104.6 & 105.8 & 107 & 108.4 & 109.4 & 110.4 & 111.8 & 113 & 114.1 & 116.2 & \\
\hline Törnqvist adjusted for tariffs and varieties & 100.5 & 103 & 105.9 & 108.2 & 109.6 & 111.5 & 113.7 & 115.5 & 117.2 & 119.2 & 121.6 & 126.2 & \\
\hline \multicolumn{14}{|l|}{ Difference from Laspeyres in annual growth rate } \\
\hline Törnqvist & -0.23 & 0.35 & 0.53 & 0.7 & 0.48 & 0 & 0 & -0.32 & 0.48 & 0.09 & 0.12 & -0.1 & 0.21 \\
\hline Törnqvist, tariffs included in prices & 0.06 & 0.55 & 0.59 & 0.81 & 0.63 & 0.1 & -0.02 & -0.14 & 0.51 & 0.16 & 0.13 & -0.12 & 0.29 \\
\hline Törnqvist adjusted for tariffs and varieties & 0.09 & 1.04 & 1.34 & 1.76 & 0.88 & 0.54 & 1 & 0.46 & 0.78 & 0.86 & 1.06 & 1.81 & 1.05 \\
\hline Contribution of ICT goods to above difference & -0.16 & 0.29 & 0.7 & 0.45 & 0.44 & -0.17 & 0.14 & -0.19 & 0.24 & 0 & 0.15 & -0.12 & 0.18 \\
\hline
\end{tabular}

\section{Notes:}

All indexes are normalized to 100 in 1994. Lower-level aggregates are at the Enduse 5-digit (or in some cases 3-digit) level. These indexes are then aggregated using the Fisher Ideal formula to obtain the higher-level aggregates, shown here. 
Table 7: Fisher Price Indexes for GDP, Total Value Added, and Value Added of Private Business adjusted for Effects of lower-Level Törnqvist Indexes, Tariffs and Variety

Ave.

$\begin{array}{lllllllllllll}1995 & 1996 & 1997 & 1998 & 1999 & 2000 & 2001 & 2002 & 2003 & 2004 & 2005 & 2006 & 96-06\end{array}$

\begin{tabular}{|c|c|c|c|c|c|c|c|c|c|c|c|c|c|}
\hline & & & & & & & & & & & & & \\
\hline \multicolumn{14}{|l|}{ I. Price index for GDP } \\
\hline baseline (official, rebased to $1994=100$ ) & 102.1 & 104 & 105.9 & 107.1 & 108.6 & 111 & 113.5 & 115.3 & 117.8 & 121.2 & 125.2 & \multicolumn{2}{|l|}{129.3} \\
\hline adjusted for Törnqvist formula & 102.1 & 104.1 & 106 & 107.2 & 108.9 & 111.3 & 113.8 & 115.6 & 118.2 & 121.6 & 125.7 & \multicolumn{2}{|l|}{129.8} \\
\hline adjusted for Törnqvist formula \& tariffs /a/ & 102.1 & 104.1 & 106 & 107.3 & 109 & 111.4 & 113.9 & 115.8 & 118.3 & 121.7 & 125.9 & \multicolumn{2}{|l|}{130} \\
\hline adjusted for Törnqvist formula, tariffs \& variety & 102.1 & 104.2 & 106.1 & 107.5 & 109.3 & 111.7 & 114.4 & 116.3 & 118.9 & 122.5 & 126.7 & \multicolumn{2}{|l|}{131.2} \\
\hline Growth rate difference from baseline for above index & 0.02 & 0.10 & 0.14 & 0.18 & 0.13 & 0.09 & 0.13 & 0.07 & 0.10 & 0.12 & 0.15 & 0.25 & 0.13 \\
\hline \multicolumn{14}{|l|}{ II. Price index for Total Value Added } \\
\hline Adjusted for Törnqvist formula /b/ & 102.1 & 104.1 & 106 & 107.2 & 108.9 & 111.3 & 113.8 & 115.6 & 118.2 & 121.6 & 125.7 & \multicolumn{2}{|l|}{129.8} \\
\hline Adjusted for Törnqvist formula \& tariffs /a/ & 102.1 & 104.1 & 106.1 & 107.4 & 109 & 111.5 & 114 & 115.9 & 118.4 & 121.9 & 126 & \multicolumn{2}{|l|}{130.1} \\
\hline Adjusted for Törnqvist formula, tariffs \& variety & 102.1 & 104.2 & 106.2 & 107.6 & 109.3 & 111.8 & 114.5 & 116.4 & 119.1 & 122.6 & 126.9 & \multicolumn{2}{|l|}{131.3} \\
\hline Growth rate difference from baseline for above index & 0.02 & 0.12 & 0.16 & 0.2 & 0.14 & 0.09 & 0.14 & 0.08 & 0.1 & 0.12 & 0.15 & 0.26 & 0.14 \\
\hline \multicolumn{14}{|l|}{ III. Price Index for Private Business Value Added } \\
\hline baseline (official, rebased to $1994=100$ ) & 101.8 & 103.4 & 105 & 105.8 & 106.6 & 108.6 & 110.5 & 111.3 & 112.9 & 115.8 & 119.6 & 123.1 & \\
\hline adjusted for Törnqvist formula & 101.8 & 103.5 & 105.2 & 106.1 & 107 & 109 & 111 & 111.8 & 113.5 & 116.5 & 120.4 & \multicolumn{2}{|l|}{124} \\
\hline adjusted for Törnqvist formula \& tariffs /a/ & 101.8 & 103.5 & 105.3 & 106.1 & 107.1 & 109.1 & 111.1 & 112 & 113.7 & 116.7 & 120.6 & \multicolumn{2}{|l|}{124.1} \\
\hline adjusted for Törnqvist formula, tariffs\& variety & 101.8 & 103.6 & 105.4 & 106.4 & 107.4 & 109.5 & 111.6 & 112.6 & 114.4 & 117.5 & 121.6 & \multicolumn{2}{|l|}{125.6} \\
\hline Growth rate difference from baseline for above index & 0.03 & 0.16 & 0.20 & 0.26 & 0.19 & 0.12 & 0.18 & 0.10 & 0.13 & 0.16 & 0.2 & 0.34 & 0.19 \\
\hline \multicolumn{14}{|l|}{ IV. Quantity Index for Private Business Value Added } \\
\hline baseline (official, rebased to $1994=100$ ) & 102.8 & 107.5 & 113.1 & 118.7 & 125.3 & 131 & 132 & 134.6 & 138.8 & 144.6 & 149.4 & 154.0 & \\
\hline adjusted for Törnqvist formula & 102.8 & 107.5 & 112.9 & 118.5 & 125 & 130.6 & 131.6 & 134.2 & 138.2 & 143.9 & 148.7 & 153.1 & \\
\hline adjusted for Törnqvist formula \& tariffs /a/ & 102.8 & 107.4 & 112.9 & 118.4 & 124.9 & 130.4 & 131.4 & 134 & 138 & 143.7 & 148.4 & 152.9 & \\
\hline adjusted for Törnqvist formula, tariffs\& variety & 102.8 & 107.4 & 112.7 & 118 & 124.4 & 129.9 & 130.7 & 133.2 & 137.1 & 142.6 & 147.1 & 151.1 & \\
\hline Growth rate difference from baseline for above index & -0.01 & -0.13 & -0.21 & -0.25 & -0.17 & -0.13 & -0.16 & -0.07 & -0.13 & -0.16 & -0.2 & -0.34 & -0.18 \\
\hline
\end{tabular}

\section{Notes:}

a. Uses tariff-inclusive price index for imports but weights aggregate imports as they are weighted in calculating GDP (i.e. excluding tariffs).

b. Tariffs in weight for imports, but not in price index for imports. 
Figure 1: U.S. Terms of Trade and Productivity

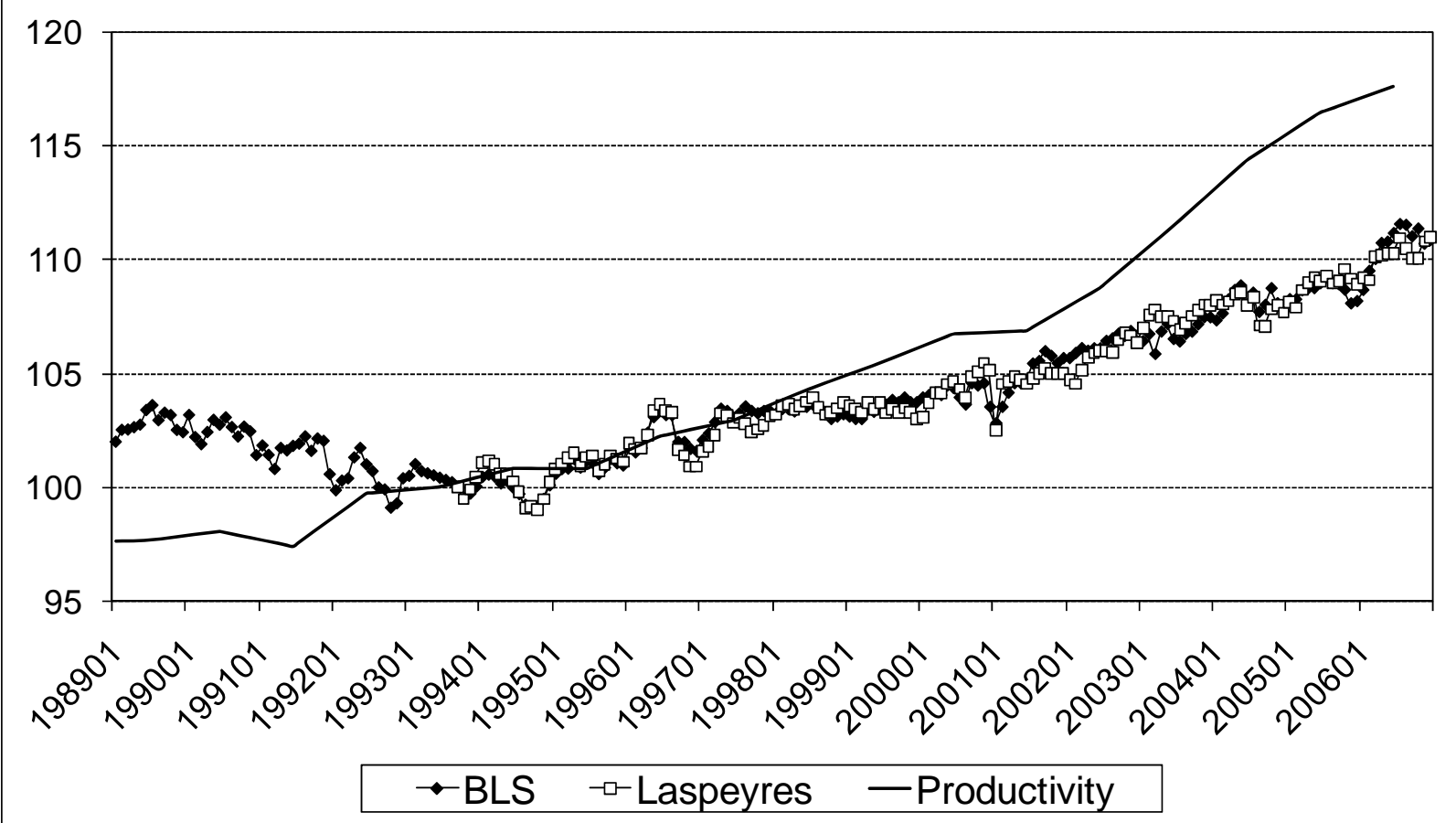

Figure 2: Alternative Terms of Trade Indexes

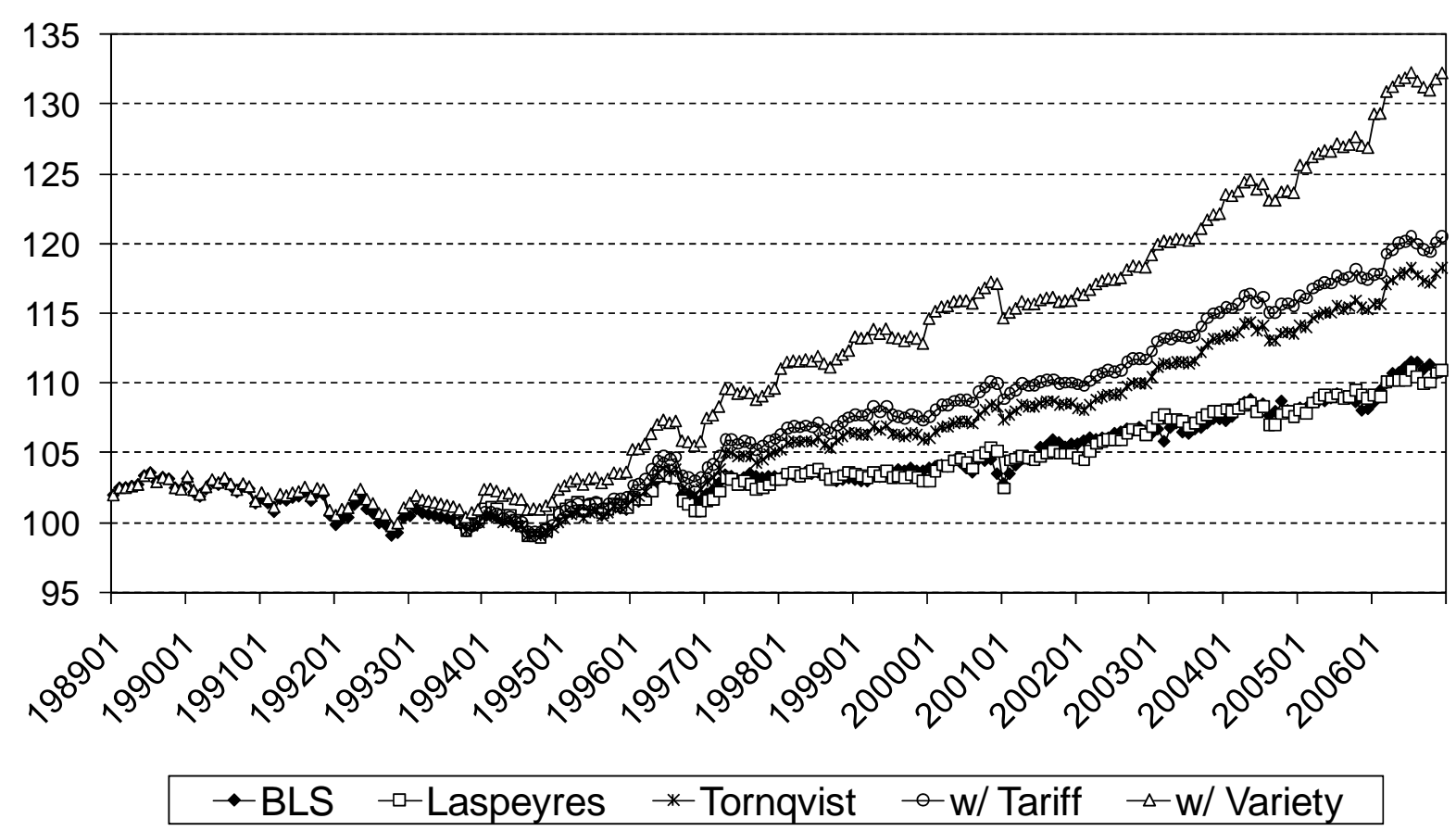


Figure 3: Import Prices, Computers (21300)

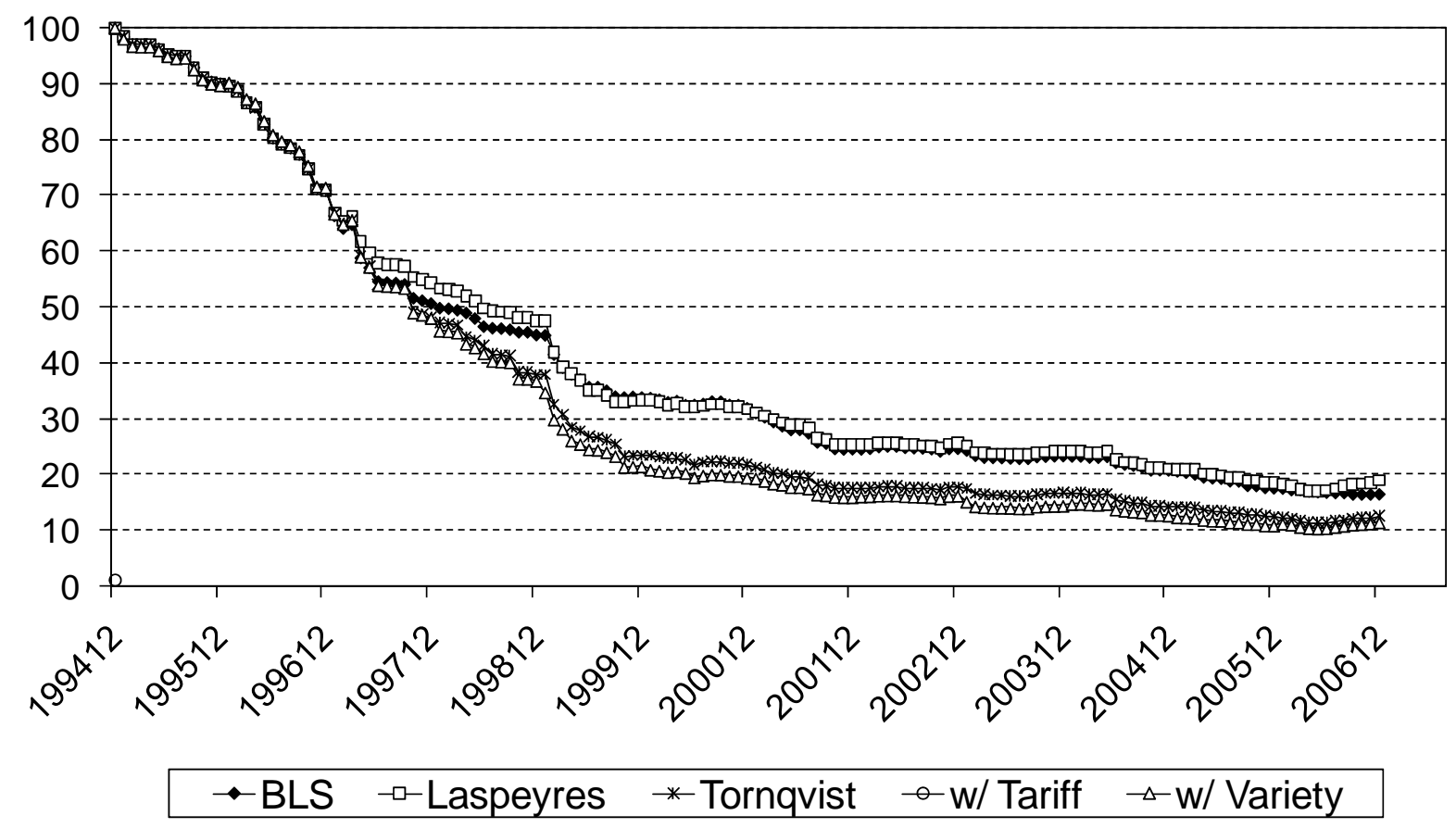

Figure 4: Export Prices, Computers (21300)

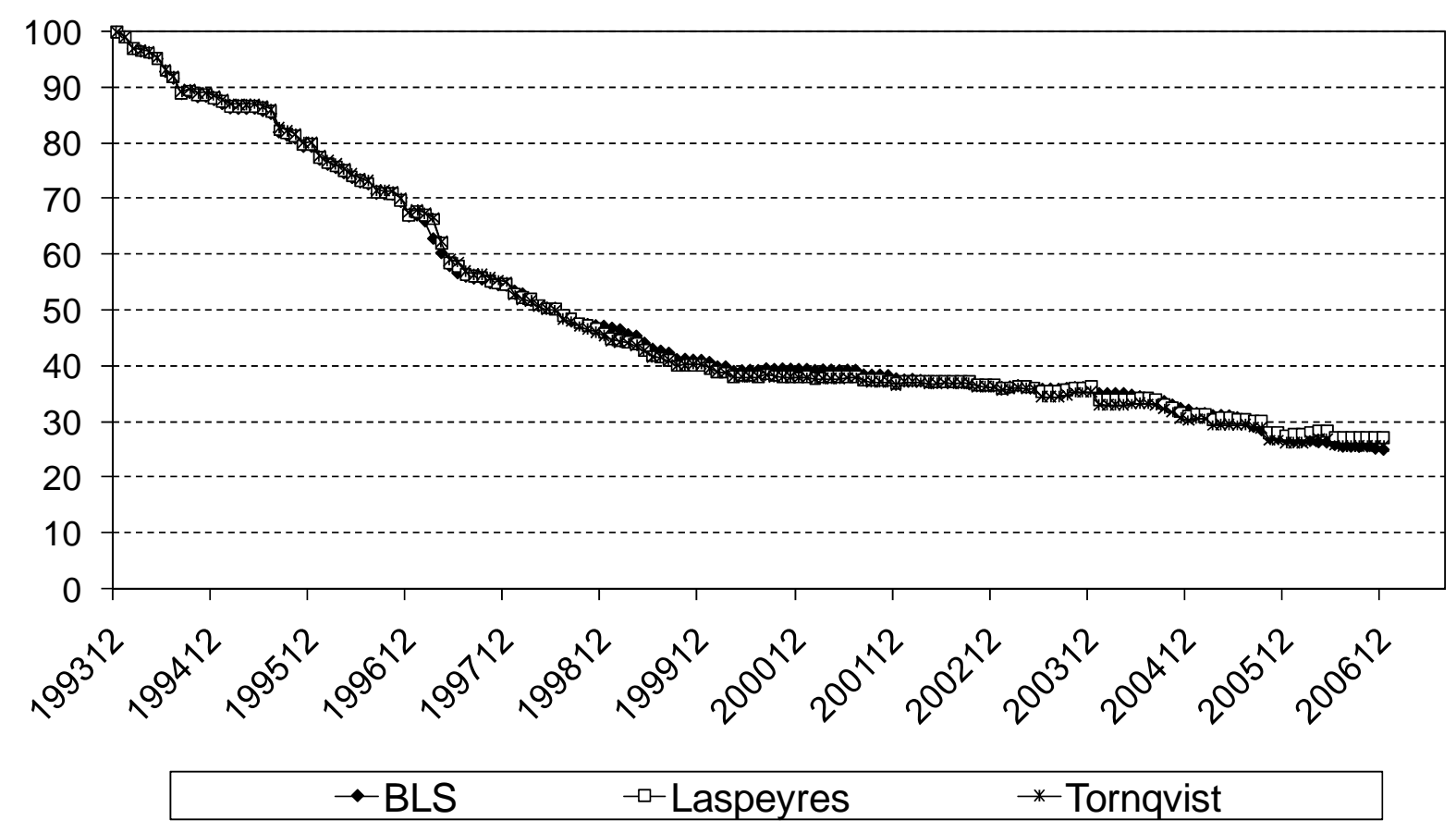



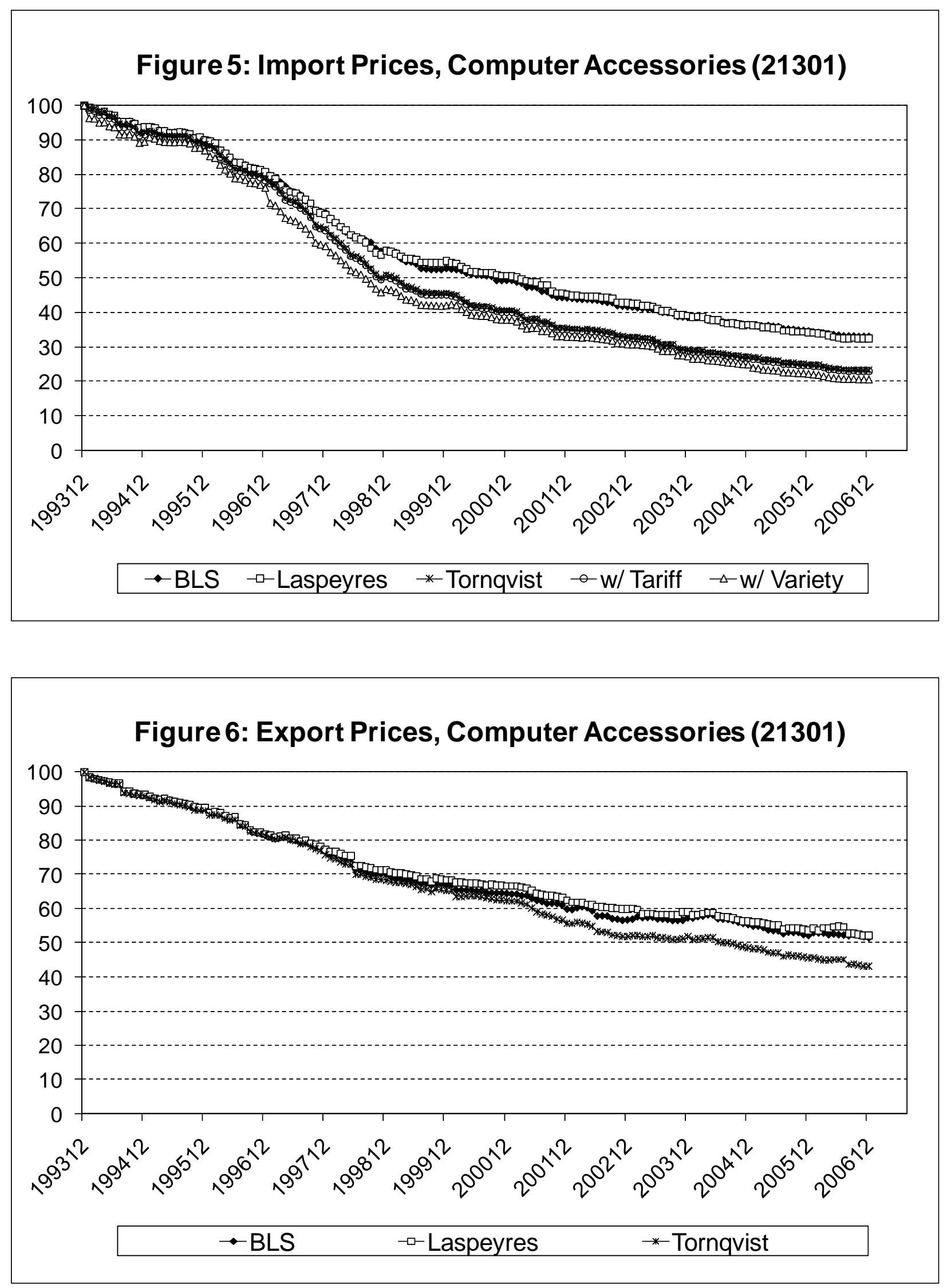
Figure 7: Import Prices, Semiconductors (21320)

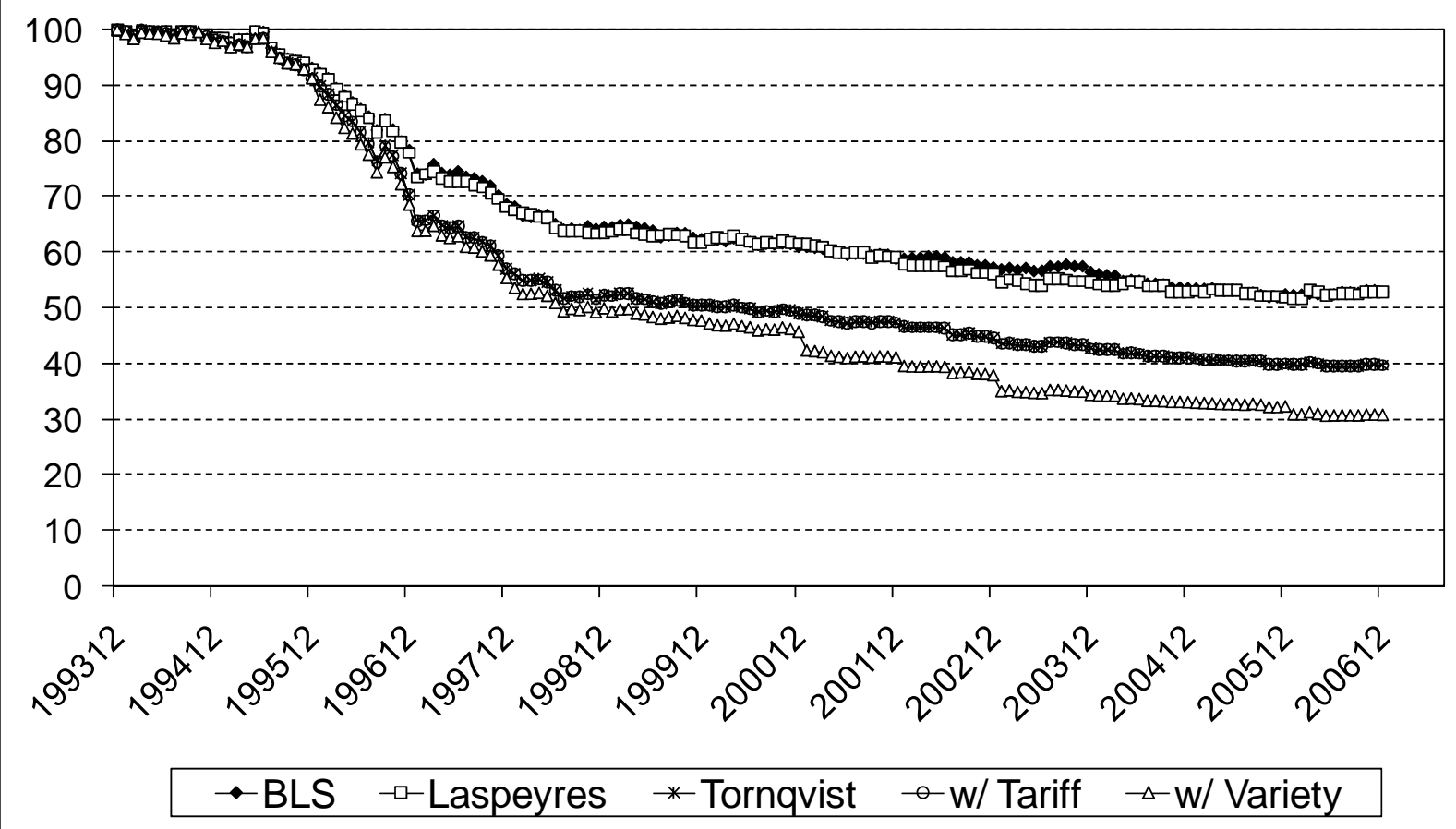

Figure 8: Export Prices, Semiconductors (21320)

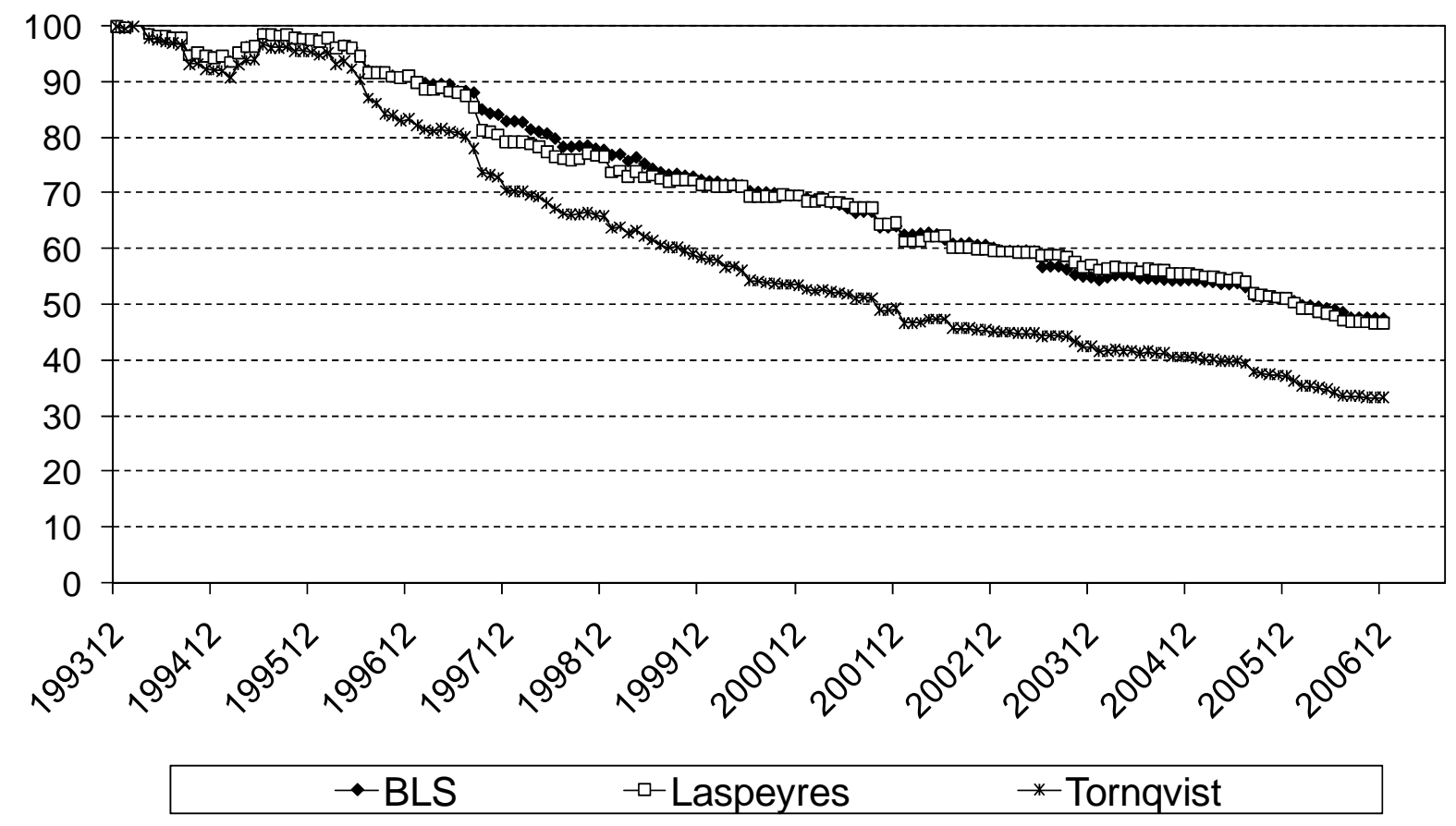


Figure 9: Import Prices, Telecommunications (21400)
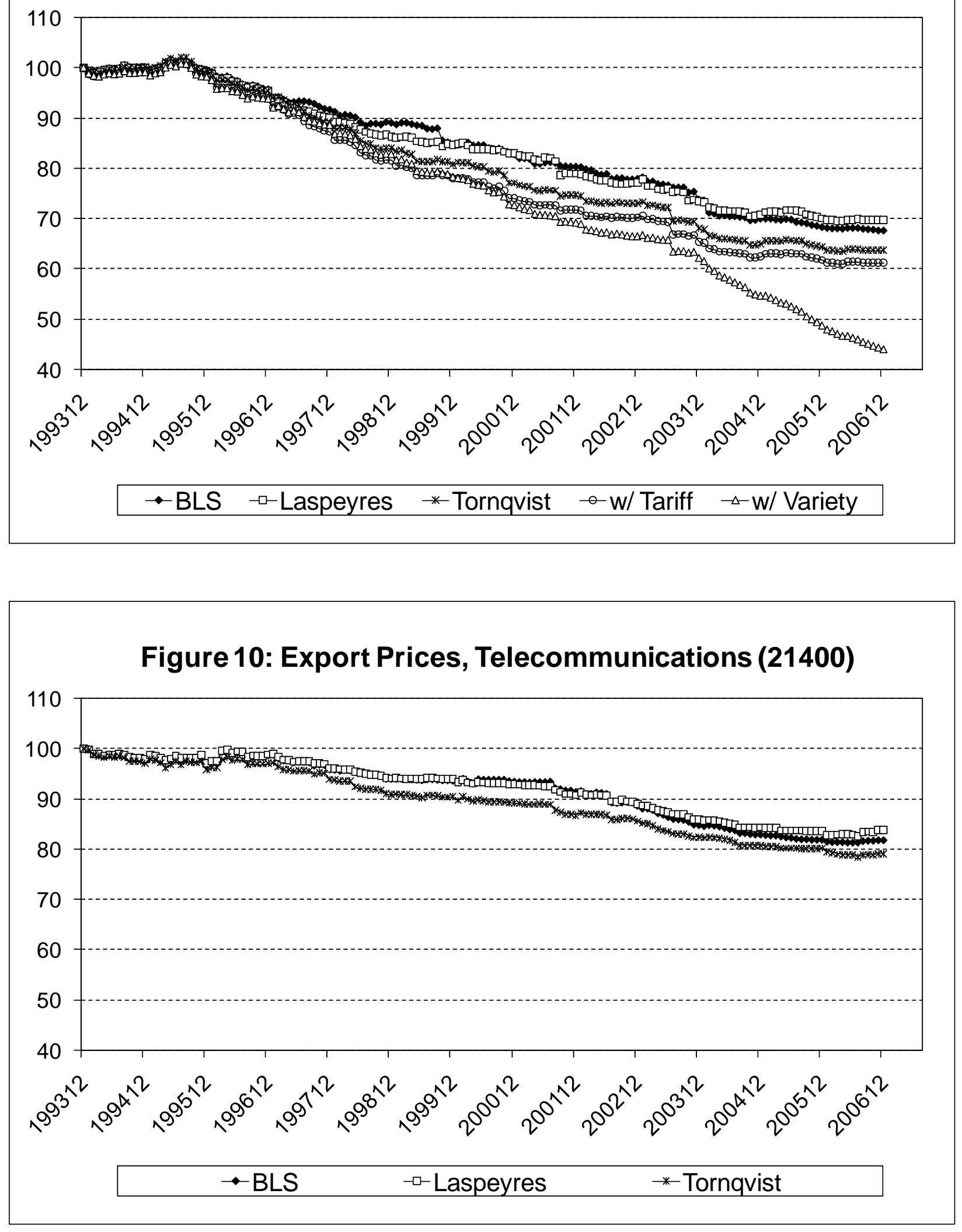